Idaho National Engineering and Environmental Laboratory
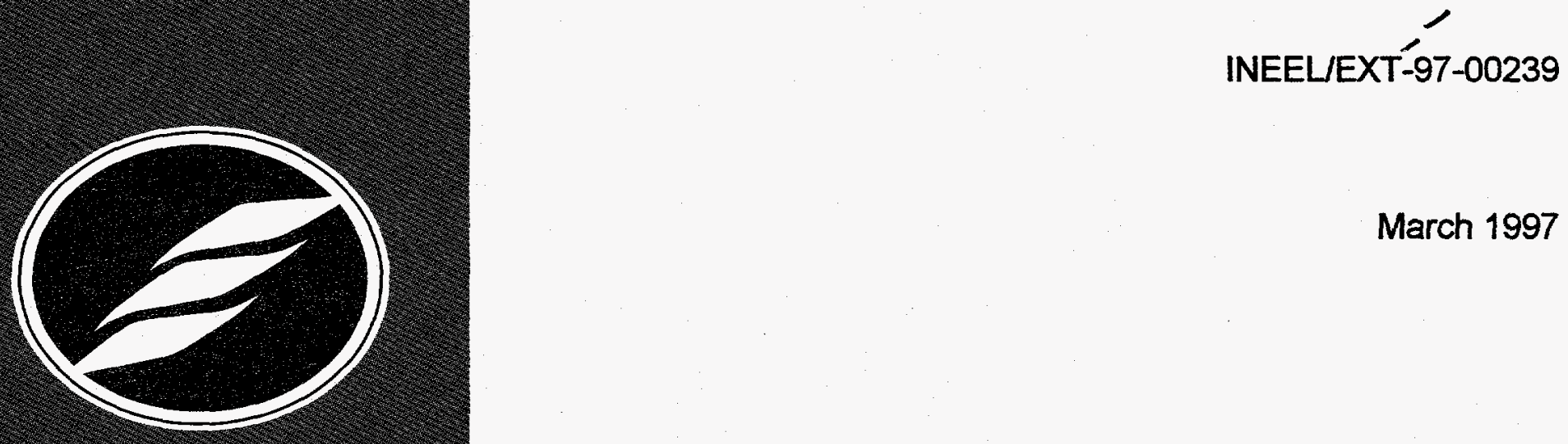

March 1997

\title{
Summary of Activities at the Engineered Barriers Test Facility, October 1, 1995, to January 31, 1997, and Initial Data
}

Indrek Porro Karen N. Keck

\section{RECEIVED}

SEP 141998

USTI

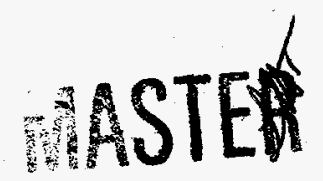

DISTRIBUTON OF THS OOCUMENT IS UNLMMTED

LOCKHEED MARTIN 


\title{
Summary of Activities at the Engineered Barriers Test Facility, October 1, 1995, to January 31, 1997, and Initial Data
}

\author{
Indrek Porro \\ Karen N. Keck
}

Published March 1997

\section{Idaho National Engineering and Environmental Laboratory Transuranic Waste Department Lockheed Martin Idaho Technologies Company Idaho Falls, Idaho 83415}

\section{Prepared for the}

U.S. Department of Energy

Assistant Secretary for Environmental Management Under DOE Idaho Operations Office

Contract DE-AC07-94ID13223 


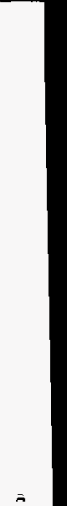




\section{DISCLAIMER}

This report was prepared as an account of work sponsored by an agency of the United States Government. Neither the United States Government nor any agency thereof, nor any of their employees, makes any warranty, express or implied, or assumes any legal liability or responsibility for the accuracy, completeness, or usefulness of any information, apparatus, product, or process disclosed, or represents that its use would not infringe privately owned rights. Reference herein to any specific commercial product, process, or service by trade name, trademark, manufacturer, or otherwise does not necessarily constitute or imply its endorsement, recommendation, or favoring by the United States Government or any agency thereof. The views and opinions of authors expressed herein do not necessarily state or reflect those of the United States Government or any agency thereof. 


\section{DISCLAIMER}

Portions of this document may be illegible in electronic image products. Images are produced from the best available original document. 


\section{ABSTRACT}

This report summarizes activities at the Engineered Barriers Test Facility from October 1, 1995, to January 31,1997 , and the initial data collected during this period. Replicates of two engineered barrier designs (a thick soil barrier and a bio/capillary barrier) were constructed in the test plots of the facility. Prior to placement of any soil in the test plots, instruments were calibrated and attached to plot instrument towers, which were then installed in the test plots. Soil from Spreading Area B was installed in the test plots in lifts and compacted. Instruments attached to the instrument tower were placed in shallow trenches dug in the lifts and buried. Each instrument was checked to make sure it functioned prior to installation of the next lift. Soil samples were collected from each lift in one plot during construction for later determination of physical and hydraulic properties. After completion of the test plots, the data acquisition system was finalized, and data collection began. Appropriate instrument calibration equations and equation coefficients are presented, and data reduction techniques are described.

Initial data show test plot soils drying throughout the summer and early fall. This corresponds to low rainfall during this period. Infiltration of water into the test plots was first detected around mid-November with several subsequent episodes in December. Infiltration was verified by corresponding measurements from several different instruments [time domain reflectometry (TDR), neutron probe, thermocouple psychrometers, and heat dissipation sensors]. Tensiometer data does not appear to corroborate data from the other instruments. Test plots were warmer on the side closest to the access trench indicating a temperature effect from the trench. This resulted in greater soil moisture freezing with less and shallower infiltration on the far side of the plots than on the side closest to the trench. At the end of this monitoring period, infiltration in all but two of the test plots has reached the $155-\mathrm{cm}$ depth. Infiltration in test plots B2 and S3 has reached only the $140-\mathrm{cm}$ depth. The monitored infiltration events have not resulted in drainage from the bottom of the test plots. 


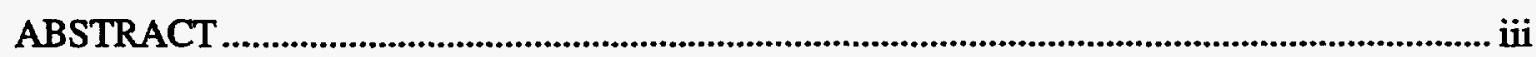

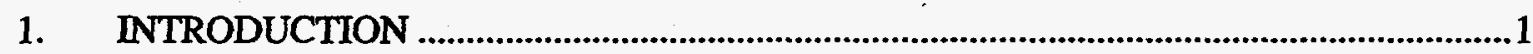

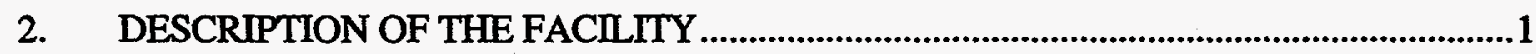

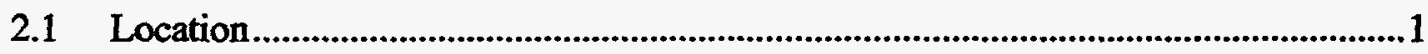

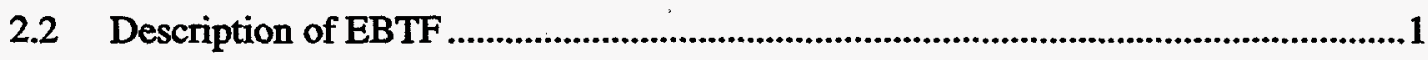

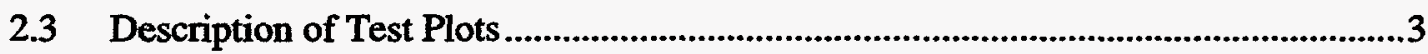

3. INSTRUMENTATION AND MEASUREMENT TECHNIQUES ....................................

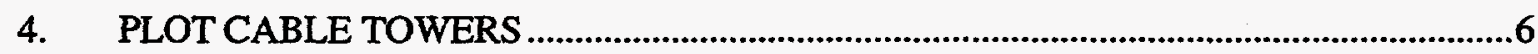

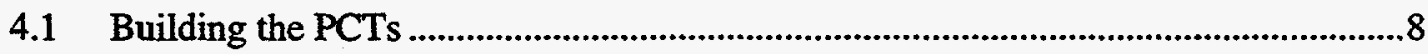

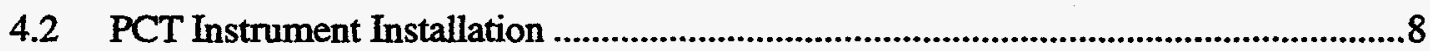

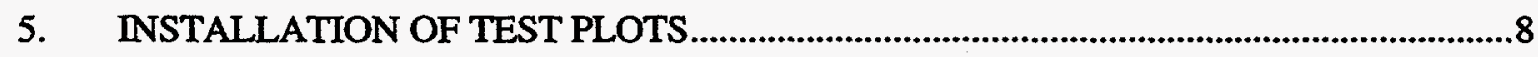

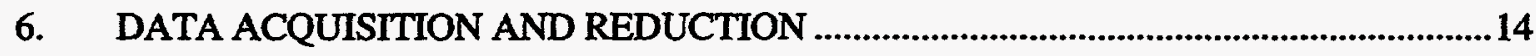

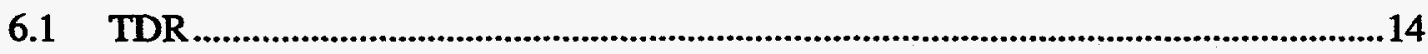

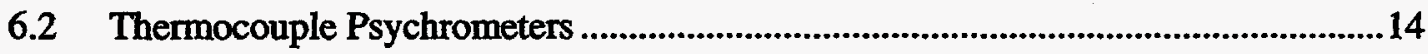

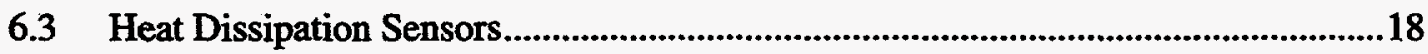

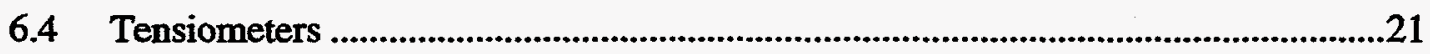

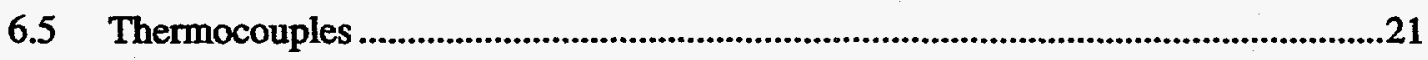

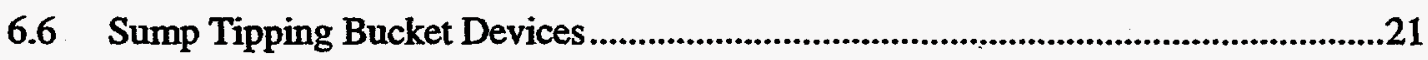

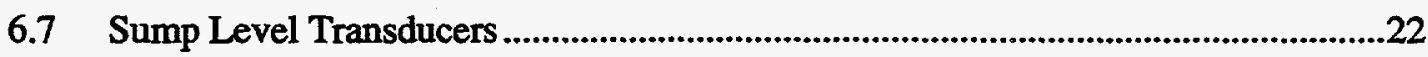

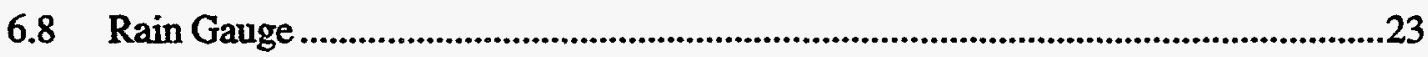

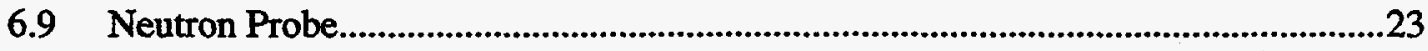




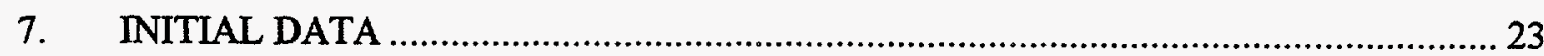

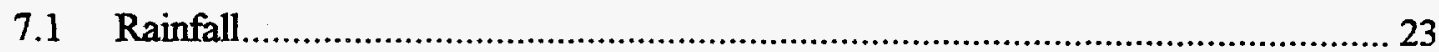

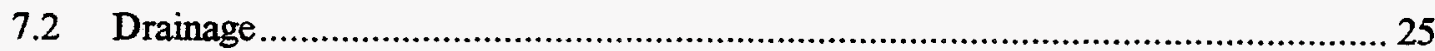

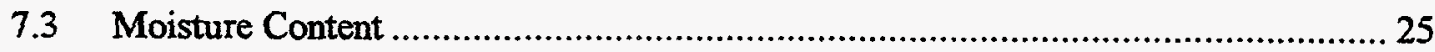

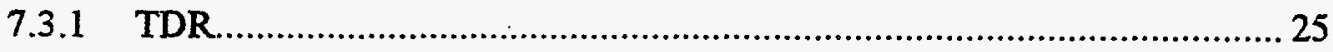

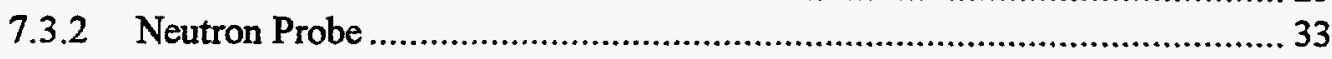

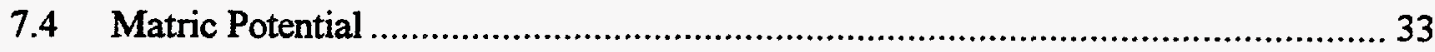

7.4.1 Thermocouple Psychrometers ....................................................... 33

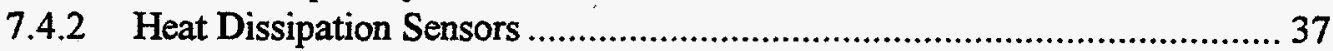

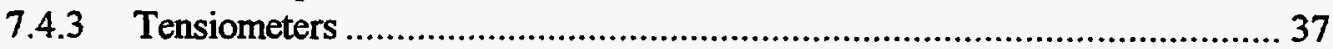

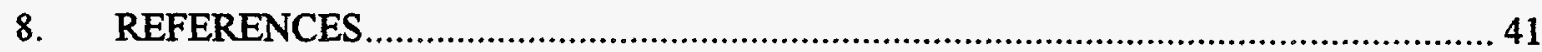

\section{FIGURES}

1. Site of the Engineered Barrier Test Facility at the INEEL. ........................................... 2

2. Schematic of the cover design (a) consisting of a thick soil and (b) incorporating a bio/capillary barrier.

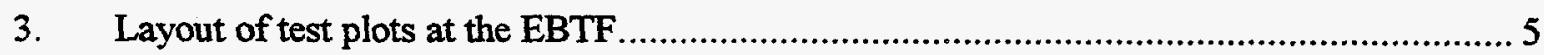

4. Plan view of a typical EBTF test plot showing instrument positions. . .......................... 7

5. Precipitation measured at the EBTF from June 26, 1996, to January $31,1997 \ldots \ldots \ldots \ldots . . . .24$

6. Cumulative drainage at the EBTF from June 26, 1996, to January 31 , 1997, as measured by the sump tipping bucket instruments.

7. Variability in soil moisture measurements from the TDR probe at the $100-\mathrm{cm}$ depth in test plot B4.

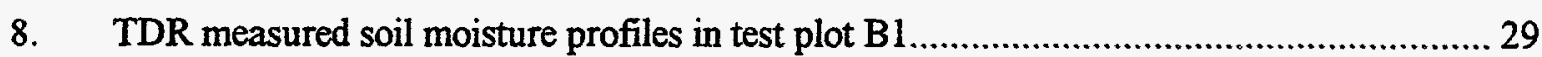

9. TDR measured soil moisture contents at the $20-\mathrm{cm}$ depth in test plot B2 (a) and corresponding soil temperature data (b).

10. Soil temperature data from thermocouple transects at the (a) $60-\mathrm{cm}$ and (b) $270-\mathrm{cm}$ depths in test plot B1. (Position 1 is farthest from the access trench wall, and position 13 is closest to the wall.) 
11. TDR soil moisture data from test plot $B 1$ illustrating the progression of infiltration at positions $02(\mathrm{a}), 06(\mathrm{~b})$, and 12 (c).

12. Neutron probe soil moisture profiles for test plots B1 ( $\mathrm{a}$ and $\mathrm{b}$ ) and $\mathrm{S} 1$ ( $\mathrm{c}$ and d).

13. TDR soil moisture profiles for test plots $\mathrm{B} 1(\mathrm{a}$ and $\mathrm{b})$ and $\mathrm{S} 1$ (c and d). 35

14. Thermocouple psychrometer data at the (a) 20-cm, (b) $60-\mathrm{cm}$, (c) $100-\mathrm{cm}$, and (d) 155 $\mathrm{cm}$ depths in test plot B1 from November 1, 1996, to January 31, 1997. 36

15. Soil temperatures at the $20-\mathrm{cm}$ depth in test plot $\mathrm{B} 1$

16. Heat dissipation sensor data at the (a) 20-cm and (b) 60-cm depths in test plot B1 from November 1, 1996, to January 31, 1997.

17. Soil matric potential profile from heat dissipation sensor data in test plot B1 on January 31,1997

\section{TABLES}

1. Locations of EBTF instruments. 6

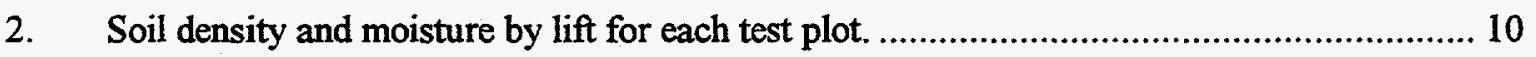

3. Thermocouple psychrometer IDs and calibration equation coefficients......................... 15

4. Heat dissipation sensor IDs and calibration equation coefficients............................... 18

5. Pressure transducer IDs and calibration equation coefficients.................................. 22 


\section{Summary Of Activities at the Engineered Barriers Test Facility, October 1, 1995, to January 31, 1997, and Initial Data}

\section{INTRODUCTION}

Field monitoring and testing, as prescribed by Porro et al. (1996), are being performed on two engineered-barrier cover designs to collect site-specific data for a detailed hydrologic performance analysis of engineered-barrier design alternatives being considered for final closure of the active low-level waste disposal area. A total of 10 test plots employing the two engineered barrier designs have been constructed and instrumented, and are being monitored.

This report provides summary descriptions of: (1) the engineered-barrier test facility (EBTF), (2) the instrumentation and measurement techniques used at the facility, (3) the installation of the test plots, (4) the data reduction methods, and (5) the initial data collected from the facility.

\section{DESCRIPTION OF THE FACILITY}

\subsection{Location}

The EBTF is located near the Radioactive Waste Management Complex (RWMC) in the southwestern corner of the Idaho National Engineering and Environmental Laboratory (INEEL) (Figure 1). The EBTF is outside the RWMC fence to the north of the Subsurface Disposal Area (SDA) in a disturbed area, used previously by U.S. Geological Survey personnel for weighing lysimeter studies. The proximity of the EBTF to the low-level waste disposal area at the SDA enhances the opportunity for testing the barriers under site specific conditions.

\subsection{Description of EBTF}

The EBTF is a concrete structure consisting of 5 cells (plots) on either side of an enclosed access trench. Each cell has four walls and a floor and measures $3 \mathrm{~m}$ wide by $3 \mathrm{~m}$ long by $3 \mathrm{~m}$ deep. The top of each cell is open to the atmosphere. Because of shallow soil at this location, soil is bermed up around the facility so that cells tops are at grade level. Each cell has two floor drains that empty into separate sumps in the access trench. One drain drains a 4-in wide trough that runs around the perimeter of the cell. The other drain drains the remaining central portion of the cell. Each drained area is sloped toward its drain. An additional opening in the floor of each cell provides a pathway for routing instrument cables from the cell to the access trench. Penetrations in the walls between the cells and the access trench provide direct access to some instruments.

The access trench is approximately $26.2 \mathrm{~m}$ long by $3.0 \mathrm{~m}$ wide by $3.8 \mathrm{~m}$ deep and serves primarily as a protected area for the data acquisition system and those instruments (tensiometers and resin capsule tubes) that penetrate the cell walls. A two-level Uni-Strut structure constructed in the trench is used to mount all the equipment enclosures for the data acquisition system. Instrument cables are routed in overhead cable raceways and along the Uni-Strut structure. A separate room at the south end of the access trench houses the data acquisition computer and serves as an office area. 


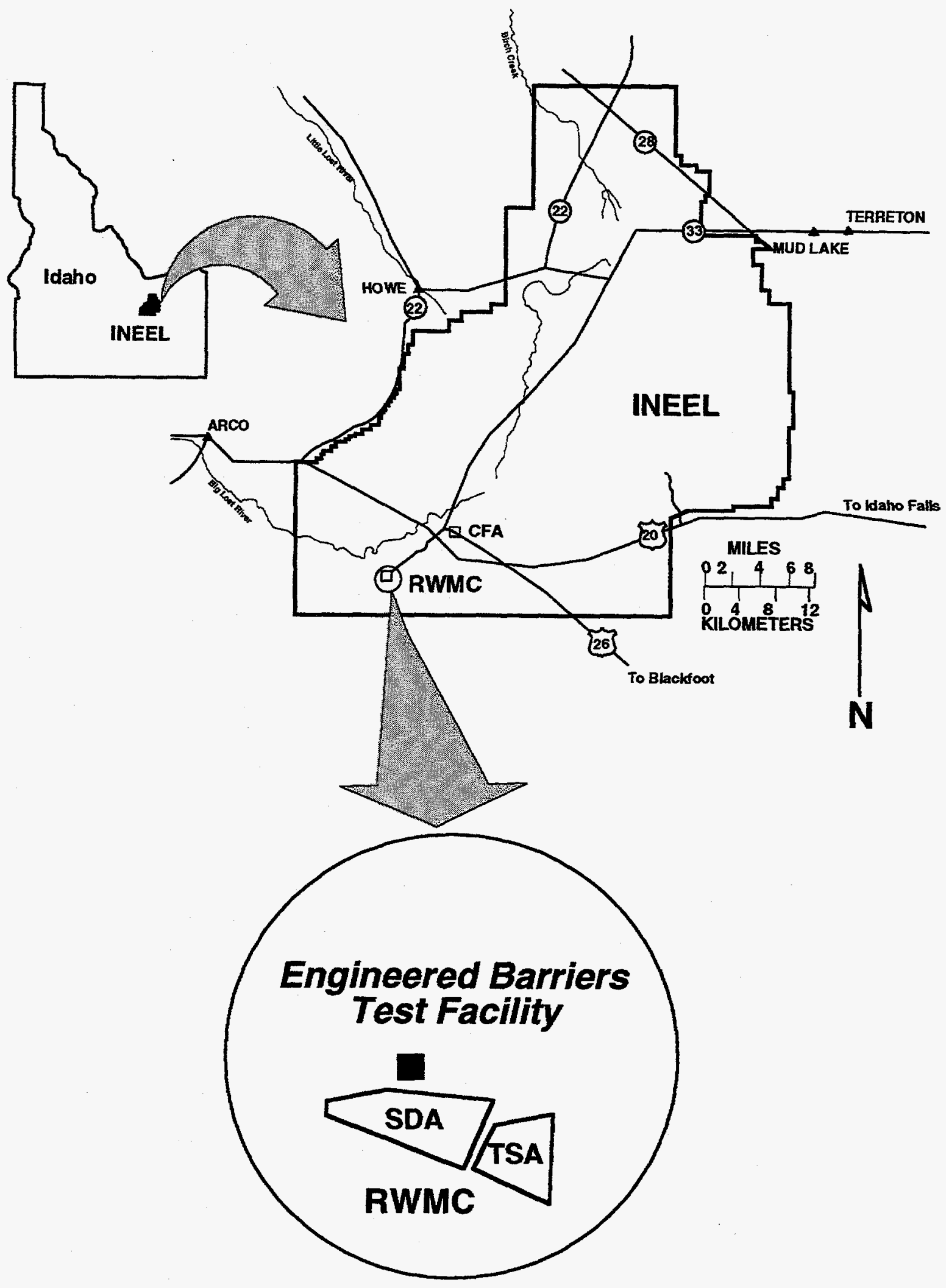

Figure 1. Site of the Engineered Barrier Test Facility at the INEEL. 
The access trench is supplied with $115-\mathrm{V}$ electrical service and a telephone line. A heat pump mounted on the south end of the roof of the access trench minimizes temperature variations and prevents freezing within the access trench.

\subsection{Description of Test Plots}

Figure 2 illustrates the two engineered barrier designs being tested at the EBTF. Four replicates of each design were built. Two test plots of each design will be subjected to natural meteorological conditions. One test plot of each design will be subjected to supplemental ( $2 \times$ normal) precipitation. One test plot of each design will be subjected to two design storm events ( a 25-yr, 24-hr storm, and a 100-yr, 24-hr storm). Two additional test plots were built with the thick soil barrier design. One of these plots will be used for in-situ hydraulic testing of the Spreading Area B cover soil. The other plot will be subject to destructive sampling and will provide additional samples for laboratory determination of hydraulic and physical properties of the cover soil. Figure 3 illustrates the layout of the test plots

\section{INSTRUMENTATION AND MEASUREMENT TECHNIQUES}

Drainage from each test plot is measured in two ways: 1) with a tipping bucket device and 2) with a pressure transducer. The tipping bucket device is attached to the drain pipe entering the sump. It serves to measure small flows (it registers one tip per $4.75 \mathrm{ml}$ of water) from the test plot. The pressure transducer rests on the floor of the sump and is used to measure the level of significant water accumulations in the sump. Readings from both types of instruments are made automatically by the EBTF data acquisition system. Details regarding all instrument types, the data acquisition system, and system configuration are provided by Kaser and Adler Flitton (1997).

Soil moisture content is measured with time domain reflectometry (TDR) and neutron probe instrumentation. The TDR probes are buried in the test plots and are read automatically by the data acquisition system. The neutron probe access tubes are installed vertically in each test plot and measurements are made manually. Table 1 and Figure 4 show the areal positions and the depths of the instruments.

Soil matric potential is measured using tensiometers, heat dissipation sensors and thermocouple psychrometers. All of these instruments are buried in the test plots (see Table 1 and Figure 4). The tensiometers are equipped with pressure transducers for automatic data acquisition. Tensiometers will function in saturated conditions and in unsaturated conditions to matric potentials of -0.8 bar. The tensiometer pressure transducers, however, were calibrated in the range 1.034 to -1.034 bars. Heat dissipation sensors and thermocouple psychrometers were calibrated in the ranges -0.5 to -10 bars and -5 to -25 bars, respectively (D.B. Stephens \& Associates, Inc., 1996). All heat dissipation sensors and thermocouple psychrometers are read automatically by the data acquisition system.

Soil temperature is measured using thermocouples buried in the test plots (see Table 1 and Figure 4). 


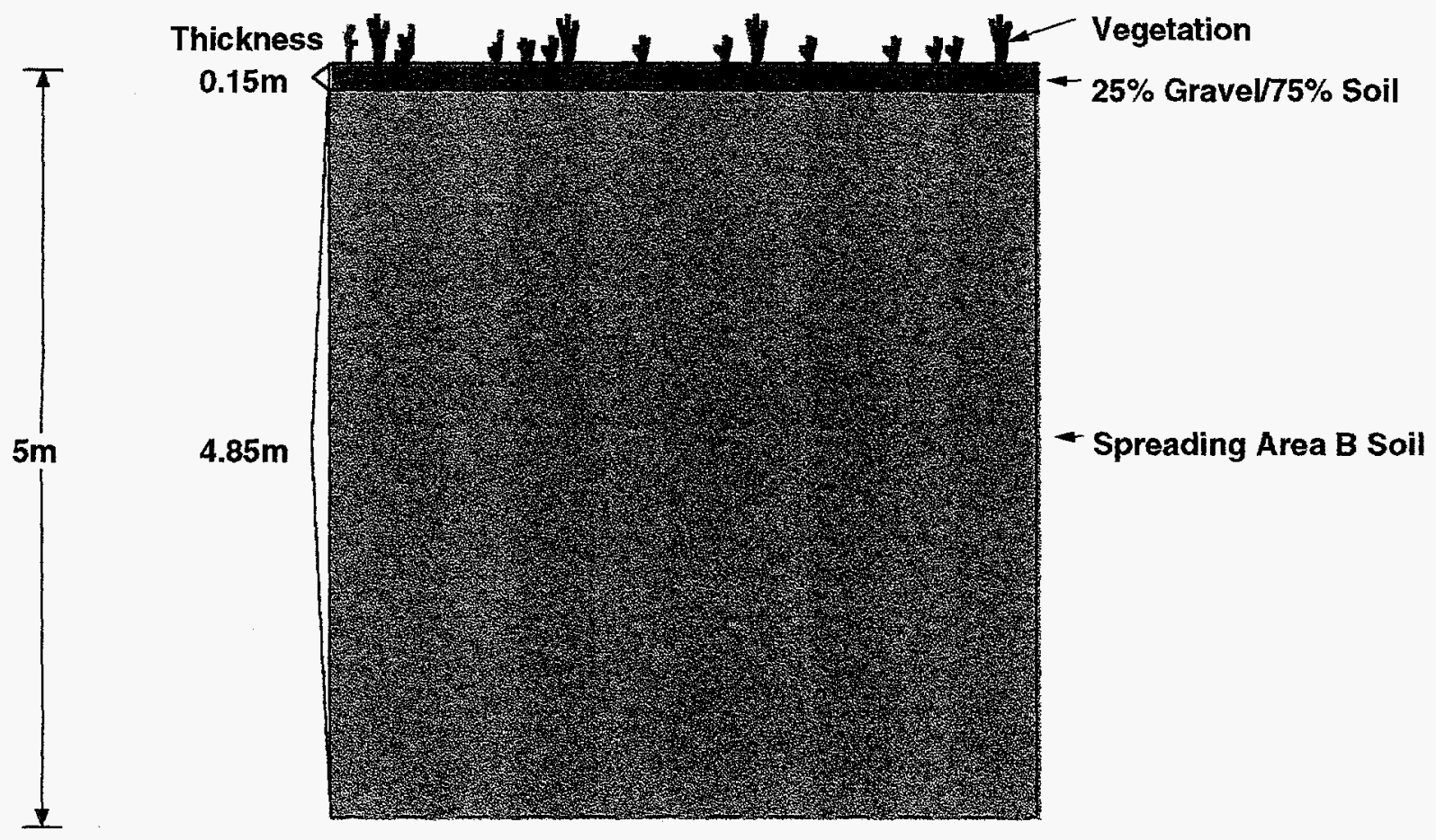

(a)

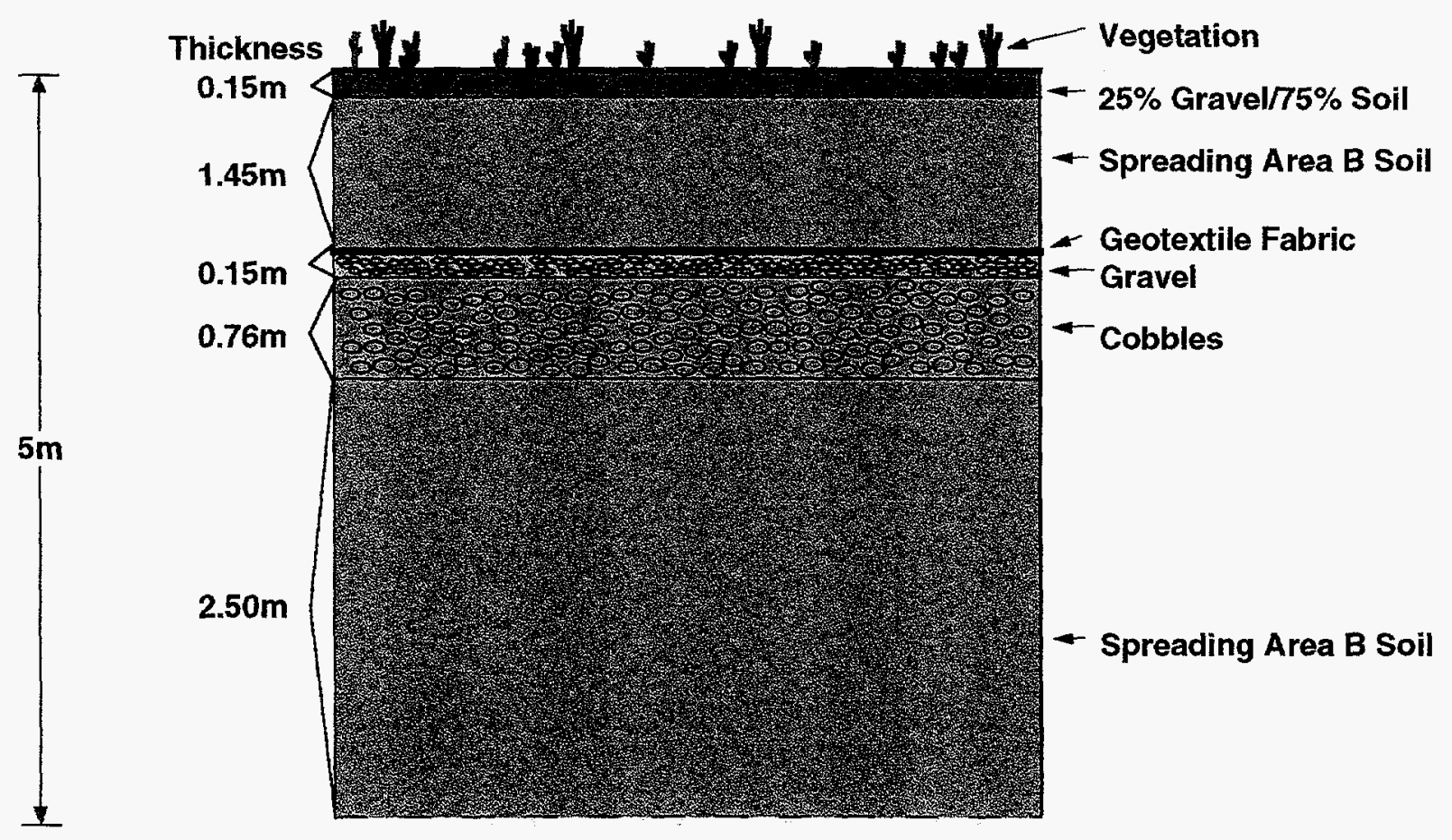

(b)

Figure 2. Schematic of the cover design (a) consisting of a thick soil and (b) incorporating a bio/capillary barrier. 


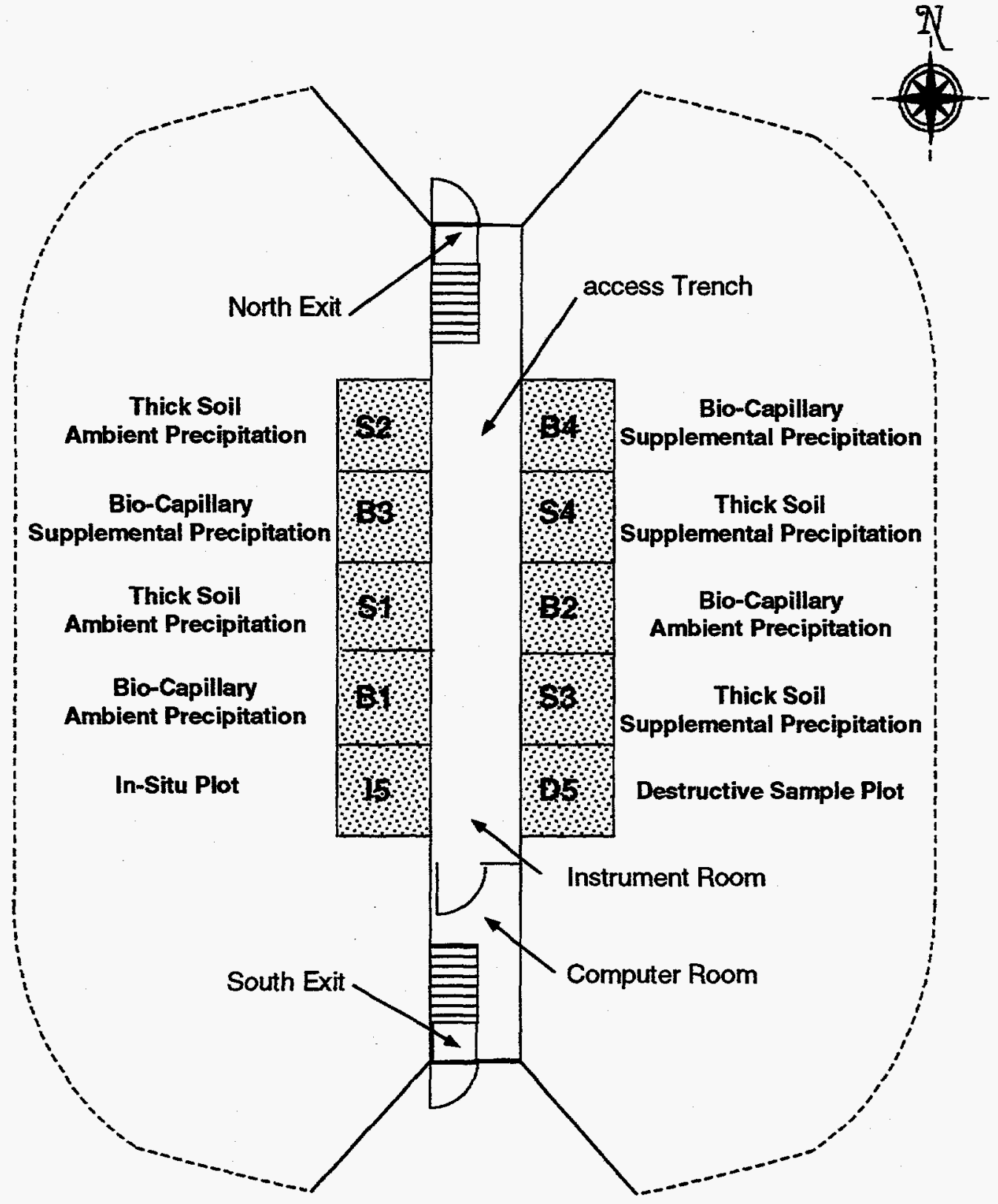

Figure 3. Layout of test plots at the EBTF. 
Table 1. Locations of EBTF instruments.

\begin{tabular}{lll}
\multicolumn{1}{c}{ Instrument } & \multicolumn{1}{c}{ Position } & \multicolumn{1}{c}{$\begin{array}{c}\text { Depth } \\
\text { (cm) }\end{array}$} \\
\hline TDR & $02,06,12$ & $20,40,60,80,100,120,140,155,(180)^{\mathrm{a}},(205),(230), 255,295$ \\
Neutron Probe & 04,08 & - \\
Tensiometer & 03,10 & $40,60,80,100,120,140,[155]^{\mathrm{b}},(180), 255,295$ \\
Thermocouple Psychrometer & 08,12 & $20,60,100,155,(205), 255,295$ \\
Heat Dissipation Sensor & 02,04 & $20,60,100,155,(205), 255,295$ \\
Thermocouple & 05,07 & $5,20,40,60,80,155,270$ \\
& $01,03,06,10,13$ & 60,270 \\
Resin Capsule & 09,11 & $80,155,255,295$ \\
\hline a. Parentheses denote depths in thick soil barrier test plots only. \\
b. Brackets denote depths in bio/capillary barrier test plots only.
\end{tabular}

Ion exchange resin capsules will be used to monitor soil water tracer movement in the test plots. Resin capsule access tubes were installed in each test plot (see Table 1 and Figure 4). These access tubes were installed horizontally through penetrations in the access trench wall. Resin capsules will be installed manually through these access tubes after a tracer is applied at the soil surface. At periodic intervals, they will be manually removed and sent to a laboratory for chemical analysis of the tracer.

Precipitation at the EBTF is measured using a tipping bucket rain gauge equipped with a heater. This rain gauge is located on the surface of the berm surrounding the test plots. The rain gauge is read automatically by the data acquisition system.

\section{PLOT CABLE TOWERS}

Cables from all instruments buried in a test plot were routed to a plot cable tower (PCT). Each PCT is centrally located within a plot and serves to minimize cable intrusions within the plot as well as provide a centralized path for cables exiting the plot. The PCT is installed vertically within the plot and does not extend to the plot surface, thereby minimizing surface penetrations and possible artificially created pathways for water flow into the plot.

Construction of the nine PCTs (the Destructive Sample plot does not have instruments) occurred in two stages. First, each PCTs pipe was cut, marked, and fitted with water tight fittings. Secondly, each PCT was loaded with all its instruments, tagged, and made ready to transport to the EBTF. 


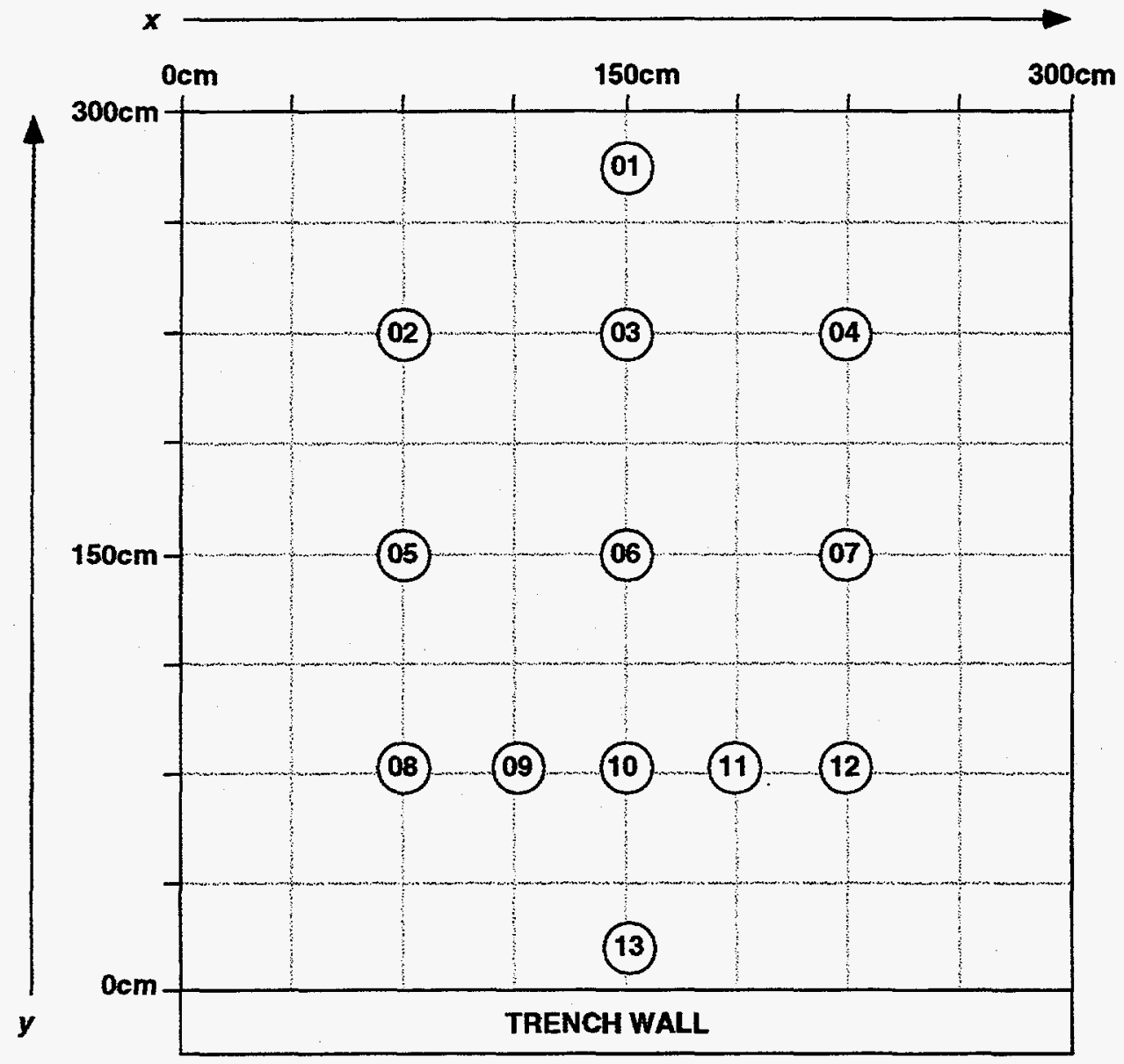

Figure 4. Plan view of a typical EBTF test plot showing instrument positions. 


\subsection{Building the PCTs}

Nine PCTs made of schedule 40 polyvinyl chloride (PVC) pipe were cut to a length of about 2.9 $m$. This length was sufficient to accommodate all of the sensors to be installed while maintaining the top of the PCT below land surface. Each PCT was then marked for penetrations at every level where instrumentation cables were scheduled to protrude from the tower. Penetrations at each level in the plot were grouped into four quadrants. Each quadrant had one to four penetrations depending on the number of instruments assigned to it. The penetrations were drilled and tapped to accept a Heyco PG-7 watertight pass-through fitting. Each fitting tightens down on the instrument cables deployed in the PCTs so that water will not pass into or out of the PCT. Teflon tape was used to stop leakage on the threads of the Heyco fittings. Thick Soil plot PCTs have 91 penetrations and Bio-Capillary plot PCTs have 78 penetrations.

\subsection{PCT Instrument Installation}

Each PCT was placed horizontally on a work rack. A cinching pull cable, housed inside of a 6.35-m tube, was fed into the PCT's bottom end to a position where a technician could see (through the penetration) the cinch loop. At that point, the instrument's cable planned for that specific location was introduced into the penetration and into the cinch loop. The cinch loop was drawn tight around the instrument cable and pulled out of the PCT bottom. This process was repeated until all instruments planned for the PCT were in place. After each instrument's cable was pulled into place, a test was conducted to validate the instrument's operation and the instrument identification tags at each end of the cable were checked.

\section{INSTALLATION OF TEST PLOTS}

The installation of the test barriers began in April 1996. Several activities were completed in each test plot prior to the placement of soil in the plot. All walls and floors were checked for cracks (no cracks were found). Guidelines were painted on the inner plot walls to aid in the placement of the soil in lifts. Both the central and edge drains were checked to make sure water flowed through them. The perforated drain plate covering the central drain was covered with a $30-\mathrm{cm}-$ by $-30-\mathrm{cm}$ patch of geotextile fabric. A thin layer of coarse sand was spread and leveled on a 91-cm-by-91-cm area over the fabric. A mesh screen and a 15-cm-by-15-cm patch of geotextile fabric were placed over the perimeter drain holes. The perimeter drain troughs were filled with pea gravel to provide a conductive pathway for any free water that may flow down the side walls of the plot. Geotextile fabric was then spread over the entire plot floor to further minimize movement of soil into the drains. A hole was cut in the geotextile fabric to accommodate the floor penetration for the PCT. Each PCT was installed onto the cable access conduit protruding from the plot floor. A schedule 80 PVC female thread to slip (glue) adapter was used and turned onto the floor cable access conduit to accommodate the bottom end of the PCT. PCT instrument cables that extended away from the PCT were pulled through the cable access conduit and collected on the trench wall while the PCT was lowered into the plot and onto the schedule 80 fitting. PVC glue was used to secure the PCT in place. The PCT was oriented so that the penetration coordinates were normal. Following PCT placement, cables in the trench were gathered into bundles for each level and type of instrument. Finally, the neutron probe access tubes were placed in their proper positions and supported at the top of the plot with a metal template designed specifically for this purpose. 
Soil for the test plots was obtained from Spreading Area B south of the RWMC and stockpiled adjacent to the EBTF. Soil was dumped into the test plot using a small front-end loader. Lines painted on the plot walls served as guides in determining the amount of soil needed to be dumped into the plot to form a lift (approximately $20 \mathrm{~cm}$ deep). The soil in the plot was then spread and compacted manually using shovels and metal tampers. After compaction, soil density and moisture measurements were made at three random locations in the plot using a surface neutron gauge. At each location, measurements were made at a minimum of two depths. The density and moisture measurements for each lift are presented in Table 2. Three lift height measurements were also made using a steel tape measure and a metal bar laid across the top of the plot walls as a reference height. Each lift was completed to a height slightly higher than the intended level of instrumentation. Shallow trenches were dug in the lift from the PCT to the intended location of each instrument. Each instrument and its associated cable were pulled out from the PCT to reach its intended location. The water-tight fittings at the PCT were then hand tightened. Each instrument and its cable were laid in the trench, and the $x-, y-$, and $z$-coordinates of the instrument were checked. Screen-sifted soil was used to backfill around the instrument to ensure good contact between the soil and instrument and the rest of the trench was filled. All TDR probes were installed horizontally and oriented in a north-south direction. Heat dissipation sensors and thermocouple psychrometers were installed horizontally with no particular regard to direction. Thermocouples were installed with no particular regard for orientation. Tensiometers were installed using a carpenter's level to ensure that tensiometer tubes were sloped with the cup end lower than the servicing end. After each instrument was buried, but before the next soil lift was placed in the plot, each instrument was tested to ensure that it was operational. The uppermost (surface) lift in each plot consists of a mixture of $25 \%$ (by volume) pea gravel and $75 \%$ (by volume) soil. The soil and gravel were mixed in a portable cement mixer. Surface lifts were spread and compacted like the other lifts, and density and moisture measurements were made similarly. All 10 test plots are currently devoid of vegetation. Plans call for establishing vegetation on all test plots and the surrounding berm in calendar year 1997. On May 16,1996, during filling of plots S1, S2, and B3, the site received approximately $2.0 \mathrm{~cm}$ of rainfall. Although all plots were covered with tarps during the rainfall, leaks in the tarps allowed water to infiltrate on all plots. Typically, these leaks occurred in isolated spots.

Installation of instruments and compaction of soil in these wet spots was extremely difficult. Therefore, the wet spots in plots S1 (at the 255-cm level), S2 (at the 180-cm level), and B3 (at the 40-cm level) were dug out and replaced with drier soil so work could continue. All other plots were left untouched because installation had already been completed.

During filling of plot D5, three grab samples and three undisturbed core samples were collected from each lift after it had been compacted. Grab samples were collected using a shovel and were double-bagged in Ziploc bags. Core samples were collected using a double-cylinder hammer-driven core sampler with 7.6- $\mathrm{cm}$ diameter by $15.2-\mathrm{cm}$ long cores. Plastic end caps were placed on the ends of each core sample, the end caps were taped in place with electrical tape, and the samples were double-bagged in Ziploc bags and placed in portable coolers with blue ice. The samples are currently in refrigerated storage awaiting shipment for analyses. The samples will be analyzed for saturated hydraulic conductivity, volumetric water content, dry bulk density, calculated total porosity, moisture characteristic, unsaturated hydraulic conductivity, particle size, particle density, and Atterberg limits.

Check-off sheets detailing what was to be done during installation in each plot, for each lift, and for each instrument were used to ensure that all activities were done in a consistent and complete manner. 
Table 2. Soil density and moisture by lift for each test plot.

\begin{tabular}{|c|c|c|c|}
\hline Plot & $\begin{array}{l}\text { Average Depth of } \\
\text { Measurements } \\
\text { (cm) }\end{array}$ & $\begin{array}{l}\text { Average Density } \\
\text { (\% of max) }\end{array}$ & $\begin{array}{l}\text { Average Moisture } \\
\text { (vol \%) }\end{array}$ \\
\hline B1 & -10.0 & 82.6 & 10.1 \\
\hline B1 & -25.8 & 84.3 & 19.3 \\
\hline B1 & -44.4 & 85.2 & 19.2 \\
\hline B1 & -62.8 & 83.1 & 18.9 \\
\hline B1 & -81.5 & 84.6 & 19.3 \\
\hline B1 & -103.8 & 85.8 & 16.4 \\
\hline B1 & -122.8 & 84.8 & 17.9 \\
\hline B1 & -139.0 & 84.1 & 18.9 \\
\hline B1 & -152.8 & 82.9 & 14.0 \\
\hline B1 & -257.6 & 84.1 & 19.4 \\
\hline B1 & -267.6 & 81.0 & 18.8 \\
\hline B1 & -283.6 & 85.9 & 21.4 \\
\hline B2 & -10.3 & 80.4 & 10.6 \\
\hline B2 & -27.4 & 83.8 & 15.9 \\
\hline B2 & -47.4 & 82.2 & 18.1 \\
\hline B2 & -63.4 & 85.7 & 15.5 \\
\hline B2 & -84.0 & 84.5 & 15.5 \\
\hline B2 & -106.0 & 80.8 & 16.1 \\
\hline B2 & -125.0 & 83.1 & 16.0 \\
\hline B2 & -137.2 & 82.5 & 16.2 \\
\hline B2 & -153.0 & 81.5 & 15.7 \\
\hline B2 & -261.5 & 81.6 & 16.5 \\
\hline B2 & -271.0 & 81.8 & 19.0 \\
\hline B2 & -293.3 & 83.0 & 17.1 \\
\hline B3 & -10.3 & 80.6 & 10.9 \\
\hline B3 & -27.7 & 83.3 & 14.8 \\
\hline B3 & -44.7 & 82.4 & 14.7 \\
\hline B3 & -58.8 & 80.6 & 14.4 \\
\hline B3 & -79.5 & 80.7 & 15.2 \\
\hline B3 & -99.0 & 82.3 & 14.4 \\
\hline B3 & -119.7 & 80.3 & 15.2 \\
\hline B3 & -140.5 & 82.3 & 15.6 \\
\hline
\end{tabular}


Table 2. (continued).

\begin{tabular}{|c|c|c|c|}
\hline Plot & $\begin{array}{c}\text { Average Depth of } \\
\text { Measurements } \\
(\mathrm{cm})\end{array}$ & $\begin{array}{l}\text { Average Density } \\
(\% \text { of } \max )\end{array}$ & $\begin{array}{c}\text { Average Moisture } \\
\text { (vol \%) }\end{array}$ \\
\hline B3 & -151.6 & 82.8 & 15.4 \\
\hline B3 & -260.2 & 78.6 & 15.9 \\
\hline B3 & -269.2 & 79.4 & 16.6 \\
\hline B3 & -291.0 & 82.3 & 14.8 \\
\hline B4 & -10.6 & 81.9 & 9.0 \\
\hline B4 & -27.7 & 81.2 & 15.0 \\
\hline B4 & -41.8 & 82.1 & 14.8 \\
\hline B4 & -60.8 & 80.5 & 14.9 \\
\hline B4 & -82.8 & 81.0 & 14.2 \\
\hline B4 & -101.8 & 85.1 & 18.6 \\
\hline B4 & -123.7 & 81.2 & 18.3 \\
\hline B4 & -138.0 & 82.0 & 18.8 \\
\hline B4 & -153.0 & 81.5 & 18.4 \\
\hline B4 & -256.6 & 83.4 & 18.4 \\
\hline B4 & -272.2 & 82.1 & 18.1 \\
\hline B4 & -290.6 & 84.3 & 18.0 \\
\hline DS & -12.6 & 81.9 & 10.9 \\
\hline DS & -30.2 & 83.0 & 17.1 \\
\hline DS & -61.6 & 86.2 & 17.3 \\
\hline DS & -102.2 & 86.9 & 17.4 \\
\hline DS & -129.9 & 86.3 & 17.5 \\
\hline DS & -159.9 & 85.0 & 18.3 \\
\hline DS & -185.6 & 85.2 & 18.7 \\
\hline DS & -215.6 & 85.2 & 19.1 \\
\hline DS & -236.3 & 81.2 & 20.4 \\
\hline DS & -250.4 & 81.1 & 18.1 \\
\hline DS & -267.8 & 83.1 & 18.1 \\
\hline DS & -289.8 & 89.7 & 19.3 \\
\hline I5 & -10.0 & 82.7 & 10.2 \\
\hline I5 & -27.7 & 83.8 & 17.1 \\
\hline I5 & -62.7 & 83.5 & 17.9 \\
\hline I5 & -93.7 & 82.6 & 18.9 \\
\hline I5 & -118.7 & 80.7 & 21.6 \\
\hline
\end{tabular}


Table 2. (continued).

\begin{tabular}{|c|c|c|c|}
\hline Plot & $\begin{array}{l}\text { Average Depth of } \\
\text { Measurements } \\
(\mathrm{cm})\end{array}$ & $\begin{array}{l}\text { Average Density } \\
\text { (\% of max) }\end{array}$ & $\begin{array}{l}\text { Average Moisture } \\
\text { (vol \%) }\end{array}$ \\
\hline 15 & -154.4 & 79.3 & 18.7 \\
\hline I5 & -181.7 & 80.6 & 18.0 \\
\hline 15 & -213.4 & 81.8 & 17.7 \\
\hline 15 & -235.1 & 80.5 & 20.3 \\
\hline I5 & -250.2 & 81.5 & 20.4 \\
\hline 15 & -267.8 & 82.8 & 20.5 \\
\hline 15 & -289.6 & 82.0 & 20.5 \\
\hline $\mathrm{S} 1$ & -10.0 & 80.7 & 10.4 \\
\hline$S 1$ & -27.4 & 83.4 & 15.5 \\
\hline S1 & -44.4 & 81.4 & 14.5 \\
\hline S1 & -61.4 & 80.6 & 15.6 \\
\hline$S 1$ & -79.4 & 82.3 & 15.4 \\
\hline $\mathrm{S} 1$ & -100.4 & 82.7 & 15.8 \\
\hline S1 & -118.0 & 82.7 & 15.4 \\
\hline $\mathrm{S} 1$ & -134.2 & 84.2 & 16.2 \\
\hline S1 & -157.7 & 81.1 & 14.7 \\
\hline $\mathrm{S} 1$ & -178.7 & 79.9 & 16.9 \\
\hline $\mathrm{S} 1$ & -204.7 & 81.9 & 15.8 \\
\hline $\mathrm{S} 1$ & -230.7 & 81.9 & 19.1 \\
\hline $\mathbf{S 1}$ & -249.8 & 81.5 & 15.2 \\
\hline S1 & -272.0 & 80.7 & 15.7 \\
\hline$S 1$ & -286.6 & 81.0 & 14.8 \\
\hline S2 & -10.6 & 82.9 & 9.8 \\
\hline S2 & -26.4 & 83.1 & 15.5 \\
\hline S2 & -44.0 & 80.5 & 16.7 \\
\hline $\mathbf{S 2}$ & -61.7 & 81.7 & 15.4 \\
\hline $\mathbf{S 2}$ & -80.0 & 83.4 & 14.4 \\
\hline S2 & -102.0 & 82.3 & 14.8 \\
\hline S2 & -122.7 & 82.0 & 15.3 \\
\hline S2 & -138.8 & 79.6 & 16.8 \\
\hline S2 & -159.7 & 80.4 & 16.7 \\
\hline $\mathbf{S 2}$ & -186.9 & 81.7 & 15.6 \\
\hline $\mathbf{S 2}$ & -211.6 & 81.8 & 13.8 \\
\hline $\mathrm{S} 2$ & -229.2 & 80.1 & 14.1 \\
\hline
\end{tabular}


Table 2. (continued).

\begin{tabular}{|c|c|c|c|}
\hline Plot & $\begin{array}{l}\text { Average Depth of } \\
\text { Measurements } \\
(\mathrm{cm})\end{array}$ & $\begin{array}{c}\text { Average Density } \\
\text { (\% of max) }\end{array}$ & $\begin{array}{l}\text { Average Moisture } \\
\text { (vol \%) }\end{array}$ \\
\hline S2 & -252.8 & 81.4 & 16.2 \\
\hline S2 & -270.7 & 80.7 & 16.3 \\
\hline S2 & -289.6 & 81.1 & 16.3 \\
\hline S3 & -10.0 & 81.1 & 9.7 \\
\hline S3 & -22.6 & 84.5 & 15.2 \\
\hline S3 & -41.2 & 82.1 & 14.7 \\
\hline S3 & -62.5 & 82.1 & 14.2 \\
\hline S3 & -83.0 & 80.6 & 16.0 \\
\hline S3 & -101.8 & 80.2 & 15.1 \\
\hline S3 & -125.5 & 80.2 & 16.6 \\
\hline S3 & -139.5 & 82.6 & 13.9 \\
\hline S3 & -158.4 & 82.1 & 13.9 \\
\hline S3 & -183.6 & 82.0 & 16.9 \\
\hline S3 & -208.9 & 82.8 & 18.2 \\
\hline S3 & -233.6 & 83.2 & 16.7 \\
\hline S3 & -253.4 & 84.3 & 15.6 \\
\hline S3 & -271.7 & 83.6 & 15.9 \\
\hline S3 & -294.0 & 80.7 & 16.8 \\
\hline S4 & -10.6 & 81.3 & 11.4 \\
\hline S4 & -29.4 & 87.2 & 17.7 \\
\hline S4 & -44.0 & 82.7 & 16.0 \\
\hline S4 & -61.0 & 85.2 & 13.1 \\
\hline S4 & -80.4 & 80.5 & 16.2 \\
\hline S4 & -103.4 & 83.4 & 15.7 \\
\hline S4 & -124.4 & 82.4 & 14.9 \\
\hline S4 & -140.8 & 82.0 & 17.6 \\
\hline S4 & -164.9 & 78.8 & 16.2 \\
\hline S4 & -180.8 & 81.6 & 14.9 \\
\hline S4 & -212.2 & 79.8 & 16.2 \\
\hline S4 & -234.0 & 79.0 & 16.8 \\
\hline S4 & -256.4 & 82.5 & 16.6 \\
\hline$S 4$ & -270.5 & 83.7 & 17.4 \\
\hline S4 & -288.3 & 80.5 & 17.4 \\
\hline
\end{tabular}




\section{DATA ACQUISITION AND REDUCTION}

Data from all instruments (except the neutron probe and resin capsules) are collected automatically using dataloggers. All dataloggers are linked to a central personal computer (PC) located at the south end of the access trench. End-to-end modems provide remote access to the central computer from the principal project scientist's office in Idaho Falls, Idaho. Detailed descriptions of the data acquisitions system including instrumentation, the instrument numbering system, datalogging equipment, system layout, datalogger program instruction sets, electrical wire configuration drawings, instrument configuration tables, recalibration schedules, acquired data file content descriptions, and instrument uncertainty analyses are presented by Kaser and Adler Flitton (1997). Acquired data files are stored on redundant personal computer data storage devices. Data reduction and analyses are currently being done using PC spreadsheet software. The following subsections describe the instrument calibration equations used to translate raw data in the acquired data files to appropriate soil parameters.

\subsection{TDR}

The TDR dataloggers are programmed to record the square root of the apparent dielectric constant, $K_{\mathrm{a}}$ from each TDR probe. The volumetric soil moisture content $\left(\theta_{\mathrm{v}}\right)$ is determined using the equation presented by Topp et al. (1980):

$$
\theta_{v}\left(m^{3} / m^{3}\right)=4.3 \times 10^{-6} K_{a}^{3}-5.5 \times 10^{-4} K_{a}^{2}+2.92 \times 10^{-2} K_{a}-5.3 \times 10^{-2} .
$$

\subsection{Thermocouple Psychrometers}

The thermocouple psychrometer dataloggers are programmed to record the temperature-corrected voltage from each thermocouple psychrometer. The matric potential $(\psi)$ is determined using the equation

$$
\psi(- \text { bars })=A \times \text { Temperature Corrected Voltage }(\mu V)-B
$$

where A and B are empirically determined coefficients. The thermocouple psychrometers were calibrated using several different molar solutions of sodium chloride (D.B. Stephens \& Associates, Inc., 1996). EBT instrument IDs and calibration laboratory IDs for the thermocouple psychrometers are reconciled in Table 3, which also contains the calibration equation coefficients. 
Table 3. Thermocouple psychrometer IDs and calibration equation coefficients

\begin{tabular}{|c|c|c|c|}
\hline Instrument ID & Laboratory ID & Coefficient A & Coefficient B \\
\hline B1TP08020 & 35666 & 2.2574 & 0.5034 \\
\hline B1TP12020 & 35672 & 2.4860 & -0.3015 \\
\hline B1TP08060 & 35662 & 2.6644 & -1.0291 \\
\hline B1TP12060 & 35670 & 2.2142 & 0.1555 \\
\hline B1TP08100 & 35653 & 2.2047 & 0.9428 \\
\hline B1TP12100 & 35641 & 2.3514 & -0.4596 \\
\hline B1TP08155 & 35660 & 2.2570 & 0.3524 \\
\hline B1TP12155 & 35655 & 2.2448 & 0.4427 \\
\hline B1TP08255 & 35644 & 2.4986 & 1.0398 \\
\hline B1TP12255 & 35658 & 2.3103 & 0.8257 \\
\hline B1TP08295 & 35648 & 2.2402 & 0.5461 \\
\hline B1TP12295 & 35663 & 2.2200 & 0.1388 \\
\hline В2ТР03020 & 35706 & 2.2616 & 0.8622 \\
\hline В2ТP10020 & 35688 & 2.2917 & 0.3031 \\
\hline В2ТР08060 & 35710 & 2.2106 & 0.9073 \\
\hline B2TP12060 & 35683 & 2.2950 & -0.6875 \\
\hline В2ТР08100 & 35687 & 2.2576 & 0.9406 \\
\hline B2TP12100 & 35699 & 2.5129 & 1.7119 \\
\hline В2ТР08155 & 35679 & 2.2765 & 0.8048 \\
\hline B2TP12155 & 35678 & 2.3515 & 0.2422 \\
\hline В2ТР08255 & 35676 & 2.2644 & 0.8580 \\
\hline В2ТР12255 & 35707 & 2.1985 & 0.3238 \\
\hline В2TP08295 & 35684 & 2.4903 & -0.7434 \\
\hline B2TP12295 & 35720 & 2.1865 & 0.7070 \\
\hline В3TP03020 & 35652 & 2.1872 & -0.1514 \\
\hline B3TP10020 & 35632 & 2.1881 & -0.1812 \\
\hline В3ТР08060 & 35628 & 2.3325 & -0.0901 \\
\hline B3TP12060 & 35659 & 2.2682 & 0.8890 \\
\hline B3TP08100 & 35650 & 2.2250 & -0.7408 \\
\hline B3TP12100 & 35625 & 2.2173 & 0.4091 \\
\hline В3TP08155 & 35626 & 6.2881 & 2.5376 \\
\hline В3TP12155 & 35620 & 2.4657 & 1.2823 \\
\hline B3TP08255 & 35633 & 2.1891 & 0.4624 \\
\hline B3TP12255 & 35638 & 1.9365 & -2.0810 \\
\hline
\end{tabular}


Table 3. (continued).

\begin{tabular}{|c|c|c|c|}
\hline Instrument ID & Laboratory ID & Coefficient A & Coefficient B \\
\hline В3TP08295 & 35675 & 2.6667 & 1.3143 \\
\hline B3TP12295 & 35637 & 2.1322 & -1.3511 \\
\hline B4TP03020 & 35673 & 2.3494 & -0.1686 \\
\hline B4TP10020 & 35636 & 2.3135 & 0.7362 \\
\hline B4TP08060 & 35667 & 2.2172 & -0.0561 \\
\hline B4TP12060 & 35669 & 2.5370 & -1.6600 \\
\hline B4TP08100 & 35674 & 2.3063 & 0.7825 \\
\hline B4TP12100 & 35668 & 2.1208 & -0.3718 \\
\hline B4TP08155 & 35634 & 2.1934 & 0.0146 \\
\hline B4TP12155 & 35661 & 2.2182 & 0.2682 \\
\hline B4TP08255 & 35664 & 2.3814 & 0.5667 \\
\hline B4TP12255 & 35671 & 2.2975 & -0.3811 \\
\hline B4TP08295 & 35704 & 2.4648 & 1.1256 \\
\hline B4TP12295 & 35665 & 2.2794 & -0.5559 \\
\hline S1TP03020 & 35703 & 2.3181 & 1.5904 \\
\hline S1TP10020 & 35694 & 2.5918 & 3.0711 \\
\hline S1TP08060 & 35711 & 2.5177 & -2.4264 \\
\hline S1TP12060 & 35677 & 2.3664 & -1.7191 \\
\hline S1TP08100 & 35635 & 2.2556 & 0.1712 \\
\hline S1TP12100 & 35698 & 2.4707 & 1.2633 \\
\hline S1TP08155 & 35642 & 2.3567 & -2.0337 \\
\hline S1TP12155 & 35716 & 2.5237 & 1.2435 \\
\hline S1TP08205 & 35645 & 2.3408 & 0.3880 \\
\hline S1TP12205 & 35702 & 2.1984 & 0.6301 \\
\hline S1TP08255 & 35643 & 2.7349 & -2.1789 \\
\hline S1TP12255 & 35646 & 2.3007 & 1.0707 \\
\hline S1TP08295 & 35695 & 2.1920 & 0.1068 \\
\hline S1TP12295 & 35647 & 2.2889 & -0.5201 \\
\hline S2TP03020 & 35715 & 3.1247 & 4.6323 \\
\hline S2TP10020 & 35692 & 2.2219 & 0.7963 \\
\hline S2TP08060 & 35705 & 3.8919 & -2.4665 \\
\hline S2TP12060 & 35640 & 2.1945 & -0.4738 \\
\hline S2TP08100 & 35682 & 2.1793 & 1.0933 \\
\hline S2TP12100 & 35722 & 2.2474 & 1.2485 \\
\hline S2TP08155 & 35723 & 3.8482 & 2.6632 \\
\hline
\end{tabular}


Table 3. (continued).

\begin{tabular}{|c|c|c|c|}
\hline Instrument ID & Laboratory $\mathrm{D}$ & Coefficient A & Coefficient B \\
\hline S2TP12155 & 35721 & 2.2501 & 1.3221 \\
\hline S2TP08205 & 35681 & 2.9200 & -1.2360 \\
\hline S2TP12205 & 35685 & 3.5352 & -2.9753 \\
\hline S2TP08255 & 35686 & 2.3215 & 0.3201 \\
\hline S2TP12255 & 35680 & 2.2062 & 0.0957 \\
\hline S2TP08295 & 35718 & 2.2214 & 0.4647 \\
\hline S2TP12295 & 35719 & 2.3080 & 1.1836 \\
\hline S3TP03020 & 35649 & 2.2142 & 0.5971 \\
\hline S3TP10020 & 35639 & 2.3124 & -1.0067 \\
\hline S3TP08060 & 35657 & 2.1595 & -0.0246 \\
\hline S3TP12060 & 35656 & 2.2967 & 0.5497 \\
\hline S3TP08100 & 35627 & 2.0786 & -1.8059 \\
\hline S3TP12100 & 35622 & 2.2659 & 0.9409 \\
\hline S3TP08155 & 35623 & 2.3551 & 1.1138 \\
\hline S3TP12155 & 35654 & 2.2047 & 0.8873 \\
\hline S3TP08205 & 35651 & 7.1511 & 2.9553 \\
\hline S3TP12205 & 35631 & 2.2109 & 0.8797 \\
\hline S3TP08255 & 35630 & 2.2241 & 0.9313 \\
\hline S3TP12255 & 35624 & 2.3005 & 0.9596 \\
\hline S3TP08295 & 35621 & 2.2231 & 0.6576 \\
\hline S3TP12295 & 35629 & 2.1295 & -0.2728 \\
\hline S4TP03020 & 35717 & 2.2081 & 0.7651 \\
\hline S4TP10020 & 35689 & 2.6093 & 0.0824 \\
\hline S4TP08060 & 35709 & 2.2495 & 0.6650 \\
\hline S4TP12060 & 35708 & 2.2387 & 0.6742 \\
\hline S4TP08100 & 35712 & 2.2890 & 1.1697 \\
\hline S4TP12100 & 35714 & 2.2420 & 0.7545 \\
\hline S4TP08155 & 35690 & 2.3205 & 0.6205 \\
\hline S4TP12155 & 35691 & 2.7470 & 0.2952 \\
\hline S4TP08205 & 35700 & 2.2539 & 0.1484 \\
\hline S4TP12205 & 35693 & 2.2839 & -0.8951 \\
\hline S4TP08255 & 35701 & 2.2135 & 0.9987 \\
\hline S4TP12255 & 35697 & 2.1698 & -0.6330 \\
\hline S4TP08295 & 35696 & 2.4987 & 0.4413 \\
\hline S4TP12295 & 35713 & 2.3316 & 1.0418 \\
\hline
\end{tabular}




\subsection{Heat Dissipation Sensors}

The heat dissipation sensor dataloggers are programmed to record the temperature differential from each heat dissipation sensor. The matric potential $(\psi)$ is determined using the equation

$$
\psi(- \text { bars })=A \times \text { Temperature Differential }\left({ }^{\circ} C\right)^{B}
$$

where $A$ and $B$ are empirically determined coefficients. The heat dissipation sensors were calibrated using pressure pot extractors (D.B. Stephens \& Associates, Inc., 1996). EBT instrument IDs and calibration laboratory IDs for the heat dissipation sensors are reconciled in Table 4, which also contains the calibration equation coefficients.

Table 4. Heat dissipation sensor IDs and calibration equation coefficients.

\begin{tabular}{lccc}
\hline Instrument ID & Laboratory ID & Coefficient A & Coefficient B \\
\hline B1HD02020 & 1684 & 0.0404 & 4.7273 \\
B1HD04020 & 1687 & 0.0389 & 4.6894 \\
B1HD02060 & 1689 & 0.0662 & 4.3717 \\
B1HD04060 & 1691 & 0.1177 & 4.1762 \\
B1HD02100 & 1682 & 0.0055 & 5.6443 \\
B1HD04100 & 1680 & 0.0088 & 5.8829 \\
B1HD02155 & 1677 & 0.0059 & 6.1388 \\
B1HD04155 & 1676 & 0.0147 & 5.1832 \\
B1HD02255 & 1674 & 0.0015 & 7.6496 \\
B1HD04255 & 1675 & 0.0434 & 4.9334 \\
B1HD02295 & 1782 & 0.1953 & 4.0480 \\
B1HD04295 & 1781 & 0.0806 & 4.6556 \\
B2HD02020 & 1757 & 0.0671 & 5.5066 \\
B2HD04020 & 1758 & 0.1296 & 4.7717 \\
B2HD02060 & 1795 & 0.0413 & 5.0974 \\
B2HD04060 & 1754 & 0.0487 & 5.5604 \\
B2HD02100 & 1793 & 0.1440 & 4.5431 \\
B2HD04100 & 1794 & 0.1249 & 4.4983 \\
B2HD02155 & 1791 & 0.1268 & 5.0156 \\
B2HD04155 & 1792 & 0.0916 & 4.8276 \\
B2HD02255 & 1790 & 0.1509 & 4.2192 \\
B2HD04255 & 1789 & 0.0963 & 4.6607 \\
B2HD02295 & 1779 & 0.2040 & 3.5630 \\
& & & \\
\hline & 163 & \\
\hline
\end{tabular}


Table 4. (continued).

\begin{tabular}{|c|c|c|c|}
\hline Instrument ID & Laboratory ID & Coefficient A & Coefficient B \\
\hline B2HD04295 & 1780 & 0.0205 & 6.1367 \\
\hline B3HD02020 & 1697 & 0.0689 & 4.2809 \\
\hline B3HD04020 & 1700 & 0.0094 & 5.4024 \\
\hline B3HD02060 & 1701 & 0.0035 & 4.6718 \\
\hline B3HD04060 & 1702 & 0.0259 & 4.6964 \\
\hline B3HD02100 & 1703 & 0.0920 & 4.3928 \\
\hline B3HD04100 & 1704 & 0.0189 & 5.0875 \\
\hline B3HD02155 & 1698 & 0.0588 & 4.5478 \\
\hline B3HD04155 & 1705 & 0.0414 & 4.5720 \\
\hline B3HD02255 & 1774 & 0.2980 & 3.3921 \\
\hline B3HD04255 & 1773 & 0.1243 & 3.7986 \\
\hline B3HD02295 & 1787 & 0.2165 & 3.9725 \\
\hline B3HD04295 & 1786 & 0.1044 & 5.0601 \\
\hline B4HD02020 & 1672 & 0.0138 & 6.3764 \\
\hline B4HD04020 & 1661 & 0.0314 & 4.9961 \\
\hline B4HD02060 & 1670 & 0.0375 & 5.1339 \\
\hline B4HD04060 & 1679 & 0.0279 & 5.8360 \\
\hline B4HD02100 & 1688 & 0.0563 & 4.3801 \\
\hline B4HD04100 & 1686 & 0.0105 & 5.1683 \\
\hline B4HD02155 & 1690 & 0.0346 & 4.9136 \\
\hline B4HD04155 & 1685 & 0.0517 & 4.4060 \\
\hline B4HD02255 & 1681 & 0.0801 & 4.0059 \\
\hline B4HD04255 & 1683 & 0.0483 & 4.5809 \\
\hline B4HD02295 & 1777 & 0.3147 & 3.3718 \\
\hline B4HD04295 & 1778 & 0.0602 & 4.9257 \\
\hline S1HD02020 & 1755 & 0.0904 & 4.5192 \\
\hline S1HD04020 & 1753 & 0.1658 & 4.2687 \\
\hline S1HD02060 & 1751 & 0.0918 & 4.6568 \\
\hline S1HD04060 & 1752 & 0.1536 & 4.4208 \\
\hline S1HD02100 & 1749 & 0.0143 & 6.0787 \\
\hline S1HD04100 & 1750 & 0.1091 & 4.6579 \\
\hline S1HD02155 & 1748 & 0.2655 & 3.6783 \\
\hline S1HD04155 & 1759 & $\mathbf{a}$ & a \\
\hline
\end{tabular}


Table 4. (continued).

\begin{tabular}{|c|c|c|c|}
\hline Instrument ID & Laboratory ID & Coefficient A & Coefficient B \\
\hline S1HD02205 & 1747 & 0.0168 & 5.6706 \\
\hline S1HD04205 & 1745 & 0.0810 & 4.8490 \\
\hline S1HD02255 & 1771 & 0.0528 & 5.2878 \\
\hline S1HD04255 & 1772 & 0.0796 & 4.9237 \\
\hline S1HD02295 & 1775 & 0.1248 & 4.6278 \\
\hline S1HD04295 & 1783 & 0.1459 & 3.7531 \\
\hline S2HD02020 & 1665 & 0.0504 & 4.3598 \\
\hline S2HD04020 & 1756 & 0.2047 & 4.0691 \\
\hline S2HD02060 & 1664 & 0.0336 & 4.8238 \\
\hline S2HD04060 & 1662 & 0.0548 & 5.1498 \\
\hline $\mathrm{S} 2 \mathrm{HD} 02100$ & 1707 & 0.0400 & 4.4419 \\
\hline S2HD04100 & 1695 & 0.0295 & 5.2959 \\
\hline S2HD02155 & 1663 & 0.0126 & 5.4111 \\
\hline S2HD04155 & 1678 & 0.0120 & 5.9371 \\
\hline S2HD02205 & 1706 & 0.0860 & 4.1246 \\
\hline S2HD04205 & 1699 & 0.0795 & 4.0506 \\
\hline S2HD02255 & 1708 & 0.1186 & 4.2939 \\
\hline S2HD04255 & 1709 & 0.0987 & 4.3401 \\
\hline S2HD02295 & 1788 & 0.1400 & 3.9151 \\
\hline S2HD04295 & 1796 & 0.0527 & 4.7923 \\
\hline S3HD02020 & .1660 & 0.0215 & 5.3710 \\
\hline S3HD04020 & 1671 & 0.0166 & 5.6880 \\
\hline S3HD02060 & 1668 & 0.0163 & 5.4928 \\
\hline S3HD04060 & 1669 & 0.0377 & 4.7066 \\
\hline S3HD02100 & 1666 & 0.0751 & 4.6257 \\
\hline S3HD04100 & 1667 & 0.0162 & 5.4280 \\
\hline S3HD02155 & 1692 & 0.0749 & 4.3681 \\
\hline S3HD04155 & 1693 & 0.0181 & 5.1759 \\
\hline S3HD02205 & 1694 & 0.0205 & 5.2959 \\
\hline S3HD04205 & 1696 & 0.0444 & 4.5233 \\
\hline S3HD02255 & 1746 & 0.0826 & 4.8623 \\
\hline S3HD04255 & 1744 & 0.1951 & 4.1093 \\
\hline S3HD02295 & 1784 & 0.2198 & 3.5078 \\
\hline
\end{tabular}


Table 4. (continued).

\begin{tabular}{cccc}
\hline Instrument ID & Laboratory ID & Coefficient A & Coefficient B \\
\hline S3HD04295 & 1785 & 0.3801 & 3.2225 \\
S4HD02020 & 1770 & 0.1597 & 4.5580 \\
S4HD04020 & 1743 & 0.0001 & 13.9020 \\
S4HD02060 & 1766 & 0.1090 & 4.6505 \\
S4HD04060 & 1769 & 0.0780 & 4.9076 \\
S4HD02100 & 1767 & 0.0643 & 5.1277 \\
S4HD04100 & 1768 & 0.0280 & 5.8677 \\
S4HD02155 & 1764 & 0.2716 & 4.5262 \\
S4HD04155 & 1765 & 0.0234 & 5.3463 \\
S4HD02205 & 1762 & 0.0147 & 6.2821 \\
S4HD04205 & 1763 & 0.1401 & 4.6707 \\
S4HD02255 & 1760 & 0.0342 & 6.1439 \\
S4HD04255 & 1761 & 0.1191 & 4.7510 \\
S4HD02295 & 1776 & 0.2327 & 3.6837 \\
S4HD04295 & 1673 & 0.0247 & 5.2036 \\
\hline a. Defective probe & & & \\
\hline
\end{tabular}

\subsection{Tensiometers}

The tensiometer dataloggers are programmed to record the voltage from each tensiometer pressure transducer. The tensiometer pressure transducers were calibrated by applying different pressures $(\mathrm{P})$ to the transducers and taking corresponding voltage readings. Pressure ( 0 to $-15 \mathrm{psi})$ is linearly related to voltage ( 0 to $-100 \mathrm{mV}$ ). Matric potential is calculated as follows:

$$
\psi(\text { bars })=\operatorname{Voltage}(m V) \times \frac{-15 p s i}{-100 m V} \times \frac{1 \text { bar }}{14.504 p s i}
$$

\subsection{Thermocouples}

The thermocouple dataloggers are programmed to record the temperature $\left({ }^{\circ} \mathrm{C}\right)$ from each thermocouple. No further reduction of this data is required.

\subsection{Sump Tipping Bucket Devices}

The sump tipping bucket datalogger is programmed to record the number of tipping bucket tips from each device. The sump tipping bucket devices are calibrated to measure $4.75 \mathrm{ml}$ of water per tip. The amount of drainage (D) is determined using the equation 


$$
D(\mathrm{~cm})=\frac{\text { Tips } \times 4.75}{\text { Area }\left(\mathrm{cm}^{2}\right)}
$$

where Area $=78,221 \mathrm{~cm}^{2}$ for the center drain and Area $=11,779 \mathrm{~cm}^{2}$ for the perimeter drain.

\subsection{Sump Level Transducers}

The sump level dataloggers are programmed to record the voltage from each sump level pressure transducer. The sump level pressure transducers were calibrated by applying different pressures $(\mathrm{P})$ to the transducers and taking corresponding voltage readings. The pressure and voltage readings are linearly related:

$$
P(p s i)=A+B \times \operatorname{Voltage}(m V)
$$

where A and B are empirically determined coefficients. Pressure is then converted to an equivalent depth of water (D) on a plot area basis using

$$
D(\mathrm{~cm})=\frac{P(p s i) \times 281,786}{\operatorname{Area}\left(\mathrm{cm}^{2}\right)}
$$

where Area $=78,221 \mathrm{~cm}^{2}$ for the center drains and Area $=11,779 \mathrm{~cm}^{2}$ for the perimeter drains. The area of each sump is $4,008.06 \mathrm{~cm}^{2}$.

EBT instrument IDs and calibration laboratory IDs for the sump level pressure transducers are reconciled in Table 5, which also contains the calibration equation coefficients.

Table 5. Pressure transducer IDs and calibration equation coefficients.

\begin{tabular}{cccc}
\hline Instrument ID & Laboratory ID & Coefficient A & Coefficient B \\
\hline B1SLOC300 & 713927 & -0.017110 & 0.000204 \\
B1SLOE300 & 713924 & 0.015255 & 0.000198 \\
B2SLOC300 & 713925 & -0.026000 & 0.000199 \\
B2SL0E300 & 713918 & -0.018880 & 0.000201 \\
B3SLOC300 & 713919 & -0.031120 & 0.000200 \\
B3SLOE300 & 713910 & -0.012100 & 0.000201 \\
B4SLOC300 & 713916 & -0.003910 & 0.000202 \\
B4SLOE300 & 713911 & -0.023680 & 0.000200 \\
D5SL0C300 & 713917 & -0.028170 & 0.000201 \\
D5SL0E300 & 713923 & -0.018480 & 0.000199 \\
I5SLOC300 & 713921 & 0.111123 & 0.000175 \\
I5SL0E300 & 713913 & 0.013477 & 0.000199 \\
S1SL0C300 & 713909 & 0.001917 & 0.000200
\end{tabular}


Table 5. (continued).

\begin{tabular}{cccc}
\hline Instrument ID & Laboratory ID & Coefficient A & Coefficient B \\
\hline S1SLOE300 & 713914 & 0.019609 & 0.000203 \\
S2SL0C300 & 713922 & 0.003099 & 0.000199 \\
S2SL0E300 & 713920 & -0.003970 & 0.000198 \\
S3SL0C300 & 713929 & 0.033386 & 0.000203 \\
S3SLOE300 & 713926 & -0.006030 & 0.000201 \\
S4SL0C300 & 713912 & -0.012100 & 0.000197 \\
S4SL0E300 & 713915 & -0.018250 & 0.000200 \\
\hline
\end{tabular}

\subsection{Rain Gauge}

The rain gauge datalogger is programmed to record the number of tipping bucket tips. The rain gauge is calibrated to measure 0.01 in. of precipitation per tip. The amount of precipitation $(P)$ is determined using the equation

$$
P(c m)=\text { Tips } \times 0.01 \times 2.54 \text {. }
$$

\subsection{Neutron Probe}

The neutron probe readings are made manually. The neutron probe readings are counts of thermalized neutrons and are converted to volumetric soil moisture content $\left(\theta_{\mathrm{v}}\right)$ using the equation for disturbed SDA sediments presented by Bishop (1996):

$$
\theta_{v}\left(m^{3} / \mathrm{m}^{3}\right)=\frac{2.396 \times 10^{-3} \times \text { Counts }+4.627}{100} .
$$

\section{INITIAL DATA}

The following subsections describe some of the initial data collected from the EBTF.

\subsection{Rainfall}

Data collection from the rain gauge at the EBTF began on June 26, 1996 (see Figure 5). Power outages at the EBTF disrupted the data acquisition system from July 20 to 23 and from August 17 to 20 . No rainfall occurred during those periods. Records from the Central Facilities Area (approximately $9 \mathrm{~km}$ northeast of the EBTF) indicate that $2.95 \mathrm{~cm}$ of rainfall occurred during filling of the test plots (April 22 to May 23), and $1.83 \mathrm{~cm}$ of rainfall occurred from the time of completion of the test plots to the start of data collection from the EBTF rain gauge (May 24 to June 25). 


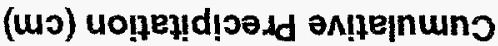

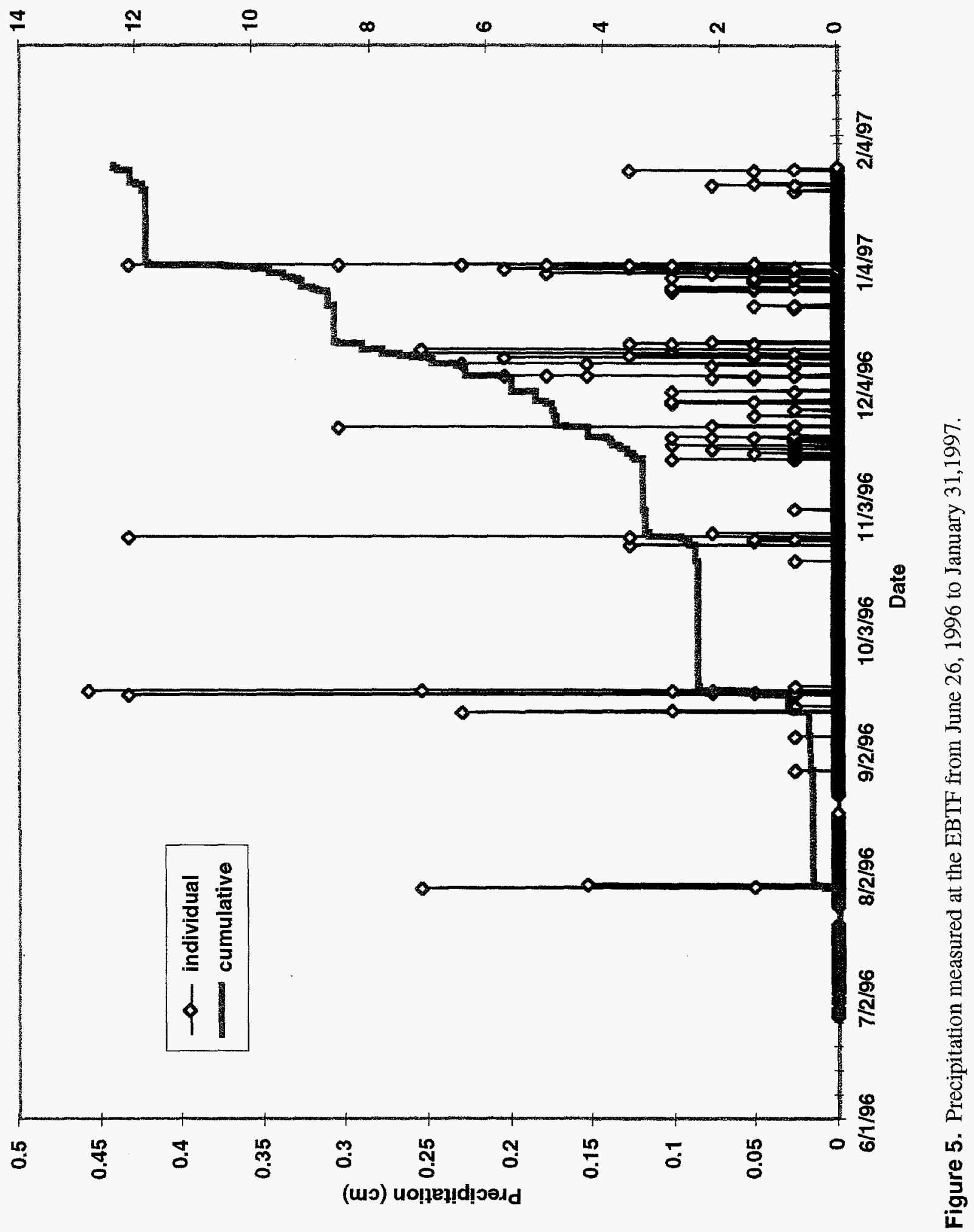




\subsection{Drainage}

Figure 6 shows cumulative drainage from the test plots from June 26, 1996, to January 31, 1997, as measured by the tipping bucket devices. Drainage from test plot B2 began on July 27 and drainage from the other plots (if it occurred) began several days later. It is unlikely that this drainage resulted from precipitation falling on the plots between the time the construction ended and drainage first occurred. From the end of construction (May 23) to July 27 , only $1.83 \mathrm{~cm}$ of rainfall occurred with the largest single day amount being $0.58 \mathrm{~cm}$. More than $73 \%$ of the total rainfall $(12.45 \mathrm{~cm})$ measured at the EBTF through January 31,1997 , has occurred after the drainage stopped, but this has not resulted in additional drainage. This suggests that the drainage that occurred resulted from rainfall during plot construction. The largest single-day rainfall $(2.03 \mathrm{~cm})$ occurred on May 16 . Although all the plots were covered with tarps during this rainfall, all of the tarps leaked. The leaks were confined to relatively small areas of the plots so that wetting occurred in spots and was not uniformly distributed across the plot surface. Test plots S1, S2, and B3 were under construction at the time. The areas of wet soil from the leaks made work difficult, if not impossible, in these plots. Therefore, the wet spots were dug out and replaced with dry soil. Plots B1, B2, B4, S3, and S4 had already been completed at this time and the decision was made not to disturb these plots. Infiltrating water concentrated in a small area of the plot probably moved fairly rapidly through the soil and resulted in drainage. Plots S1, S2, and B3, in which the wet spots were dug out, did not exhibit much drainage.

Although sumps for the draining plots did collect some water, levels were too low to be measured with the sump level transducers.

\subsection{Moisture Content}

Moisture contents in the test plots are measured using TDR and neutron probe instrumentation. These two instruments complement each other and one serves as a backup to the other in case instrument problems arise.

\subsubsection{TDR}

Initial TDR data from a number of probes exhibited variability to the degree that determining changes in soil moisture over time could have been problematic. Figure 7 illustrates one of the more extreme examples of this variability. Moisture contents measured in September (during a period of very little rainfall and virtually no infiltration) varied approximately $0.07 \mathrm{~m}^{3} / \mathrm{m}^{3}$. Considering all the TDR probes, the mean variation (maximum reading minus minimum reading for each probe) for a 5 -day period in July was $0.0261 \mathrm{~m}^{3} / \mathrm{m}^{3}$. The corresponding standard deviation was $0.0057 \mathrm{~m}^{3} / \mathrm{m}^{3}$. Several things were done to reduce the variability. First, the apparent electrical length of each probe's cable was determined and Parameter No. 4 of each Instruction 100 in the TDR datalogger program was set to a value $0.4 \mathrm{~m}$ less than the shortest cable length attached to that multiplexer. Second, a dc-to-dc converter was installed in-line with the power from the batteries to maintain a constant power source. This unit provides constant $12.5 \mathrm{Vdc}$ power to the system even though the actual supply power (battery) may range from 9 to $18 \mathrm{Vdc}$. Power supply noise was further reduced by installing several large capacitors at each power block and a coil in-line with the positive lead cable (Kaser and Adler Flitton 1997). Third, waveform averaging by the TDR datalogger was increased to its maximum allowable value (128). With all these changes, the mean variation for a 5-day period at the end of November was $0.0093 \mathrm{~m}^{3} / \mathrm{m}^{3}$. The corresponding standard deviation was $0.0023 \mathrm{~m}^{3} / \mathrm{m}^{3}$. This represents a $65 \%$ reduction in the mean variation (maximum value minus minimum value) and a $60 \%$ reduction in the standard deviation. 

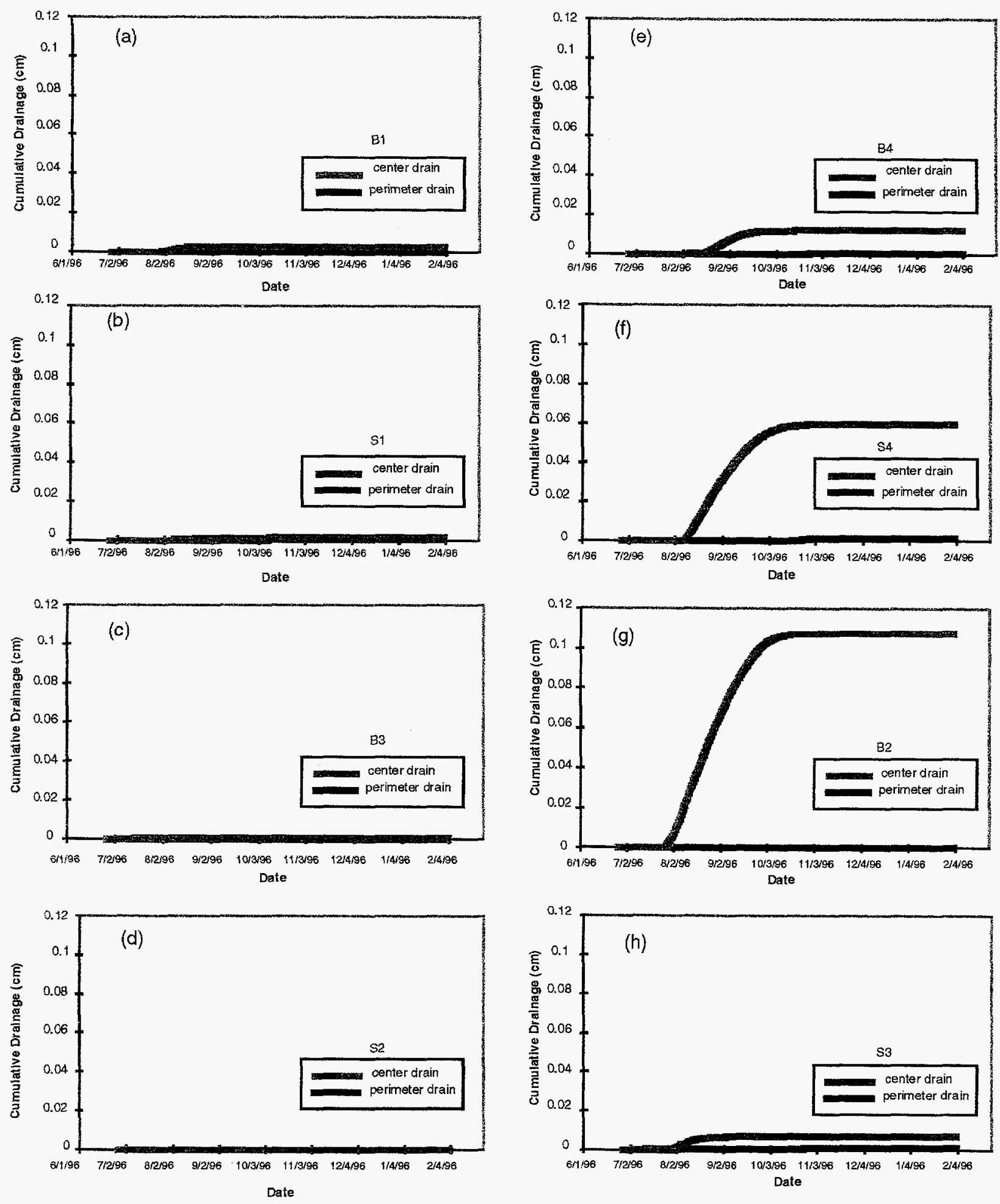

Figure 6. Cumulative drainage at the EBTF from June 26, 1996 to January 31, 1997 as measured by the sump tipping bucket instruments. 


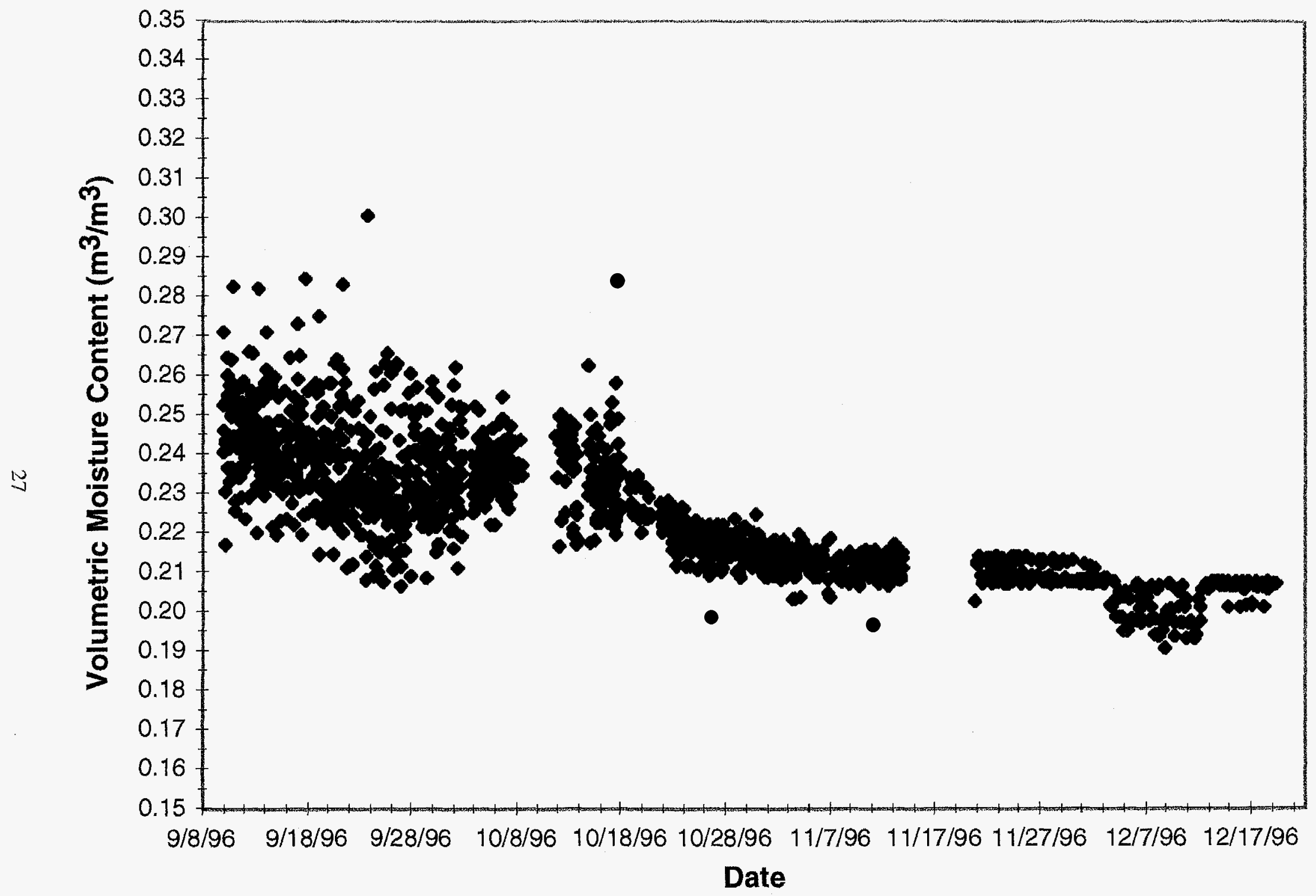

Figure 7. Variability in soil moisture measurements from the TDR probe at the 100-cm depth (position 12) in test plot B4. 
In spite of the variability, the TDR data can be used to describe moisture conditions in the test plots. Figure 8 illustrates the general pattern of soil moisture in the engineered barrier test plots. Little rain $(3.35 \mathrm{~cm}$ ) fell between July 27 and November 14, resulting in significant drying of the profile to the depth of the bio/capillary barrier. Between November 14 and $21,0.94 \mathrm{~cm}$ of rainfall resulted in the first measured infiltration (to a depth of $20 \mathrm{~cm}$ ). Precipitation frequency increased after November 21 with December and January totals being greater $(+2.64 \mathrm{~cm}$ and $+0.97 \mathrm{~cm}$, respectively) than the long-term average. By January 24, infiltration had reached the bio/capillary barrier but had not breached it. Wetting patterns were the same in the thick soil test plots.

TDR is used to determine soil moisture by measuring the dielectric constant of the medium surrounding the probe. The soil bulk dielectric constant is governed by the dielectric constant of water (approximately 81 ) because the dielectric constants of the other soil constituents are much smaller (soil minerals $=3$ to 5 , air $=1$ ). Since soil minerals do not change, changes in dielectric constant can be attributed to changes in moisture content. However, the dielectric constant of frozen water (ice) is approximately 4 , so the TDR measures only liquid water content, not total water content. EBTF data illustrate this phenomenon (see Figure 9). TDR position 6 and thermocouple positions 5 and 7 are all located midway in the plot between the access trench wall and the opposite wall. TDR position 2 is located farthest from the trench wall, and TDR position 12 is located closest to the trench wall. Initially, soil temperatures were above freezing and soil moisture at all three probe locations at the 20-cm depth was gradually being redistributed to other depths. On December 4, soil temperatures dropped below freezing and the moisture content at positions 2 and 6 decreased abruptly from about $0.24 \mathrm{~m}^{3} / \mathrm{m}^{3}$ to about $0.17 \mathrm{~m}^{3} / \mathrm{m}^{3}$. Approximately $0.07 \mathrm{~m}^{3} / \mathrm{m}^{3}$ of the moisture had turned to ice. On December 10 , soil temperatures rose above freezing and the moisture contents at positions 2 and 6 increased abruptly. Frozen water melted and moisture contents at all three positions increased due to additional infiltration from snowmelt. Moisture contents at positions 2 and 6 decreased abruptly again on December 15 when the temperature again dropped below freezing. This time approximately $0.29 \mathrm{~m}^{3} / \mathrm{m}^{3}$ of the moisture froze due to the greater amount of moisture available and the lower temperatures. Moisture contents at position 12 did not respond to the freezing and thawing temperatures as at the other two positions because position 12 is generally warmer than the other positions. Thermocouple transects across the plot (from the access trench side to the far side) at the 60 -and $270-\mathrm{cm}$ depths show that soil temperatures were warmer on the side closest to the trench (see Figure 10). It is assumed that this effect was evident also at the $20-\mathrm{cm}$ depth. Soil temperatures at position 12 apparently did not go below freezing during this period.

Figure 11 illustrates the effect of differential freezing on infiltration in test plot B1. The greatest amount of freezing occurred at position 2 (Figure 11a). Infiltration at this position reached the $60-\mathrm{cm}$ depth. Moisture levels at lower depths did not change and are not shown. Closer to the access trench, at a location where less freezing occurred (Figure 11b), infiltration during the same period reached the 100-cm depth. Again, moisture levels at lower depths did not change and are not shown. At position 12 (Figure 11c), where little, if any, freezing occurred, infiltration reached the $155-\mathrm{cm}$ depth. Moisture levels below the bio/capillary barrier have not changed and are not shown. Similar effects occurred in the other test plots. The differences in depth of infiltration across the test plot may be due also to somewhat greater snow accumulations on the test plot near the access trench wall. During windy conditions, snow drifts form next to the trench wall. If this snow melts when the soil is not frozen, more water may infiltrate on this side of the test plot. 


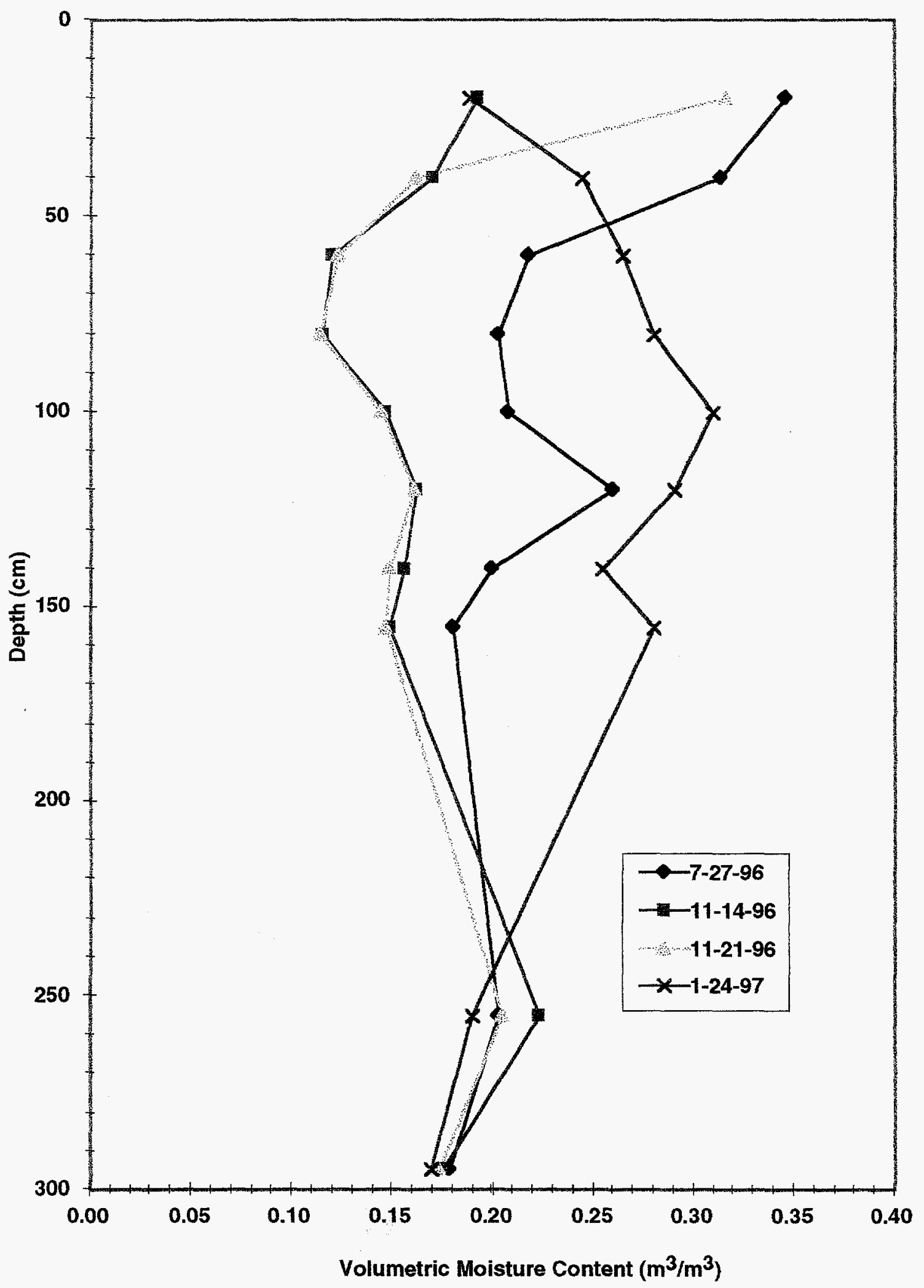

Figure 8. TDR-measured soil moisture profiles in test plot B1. 

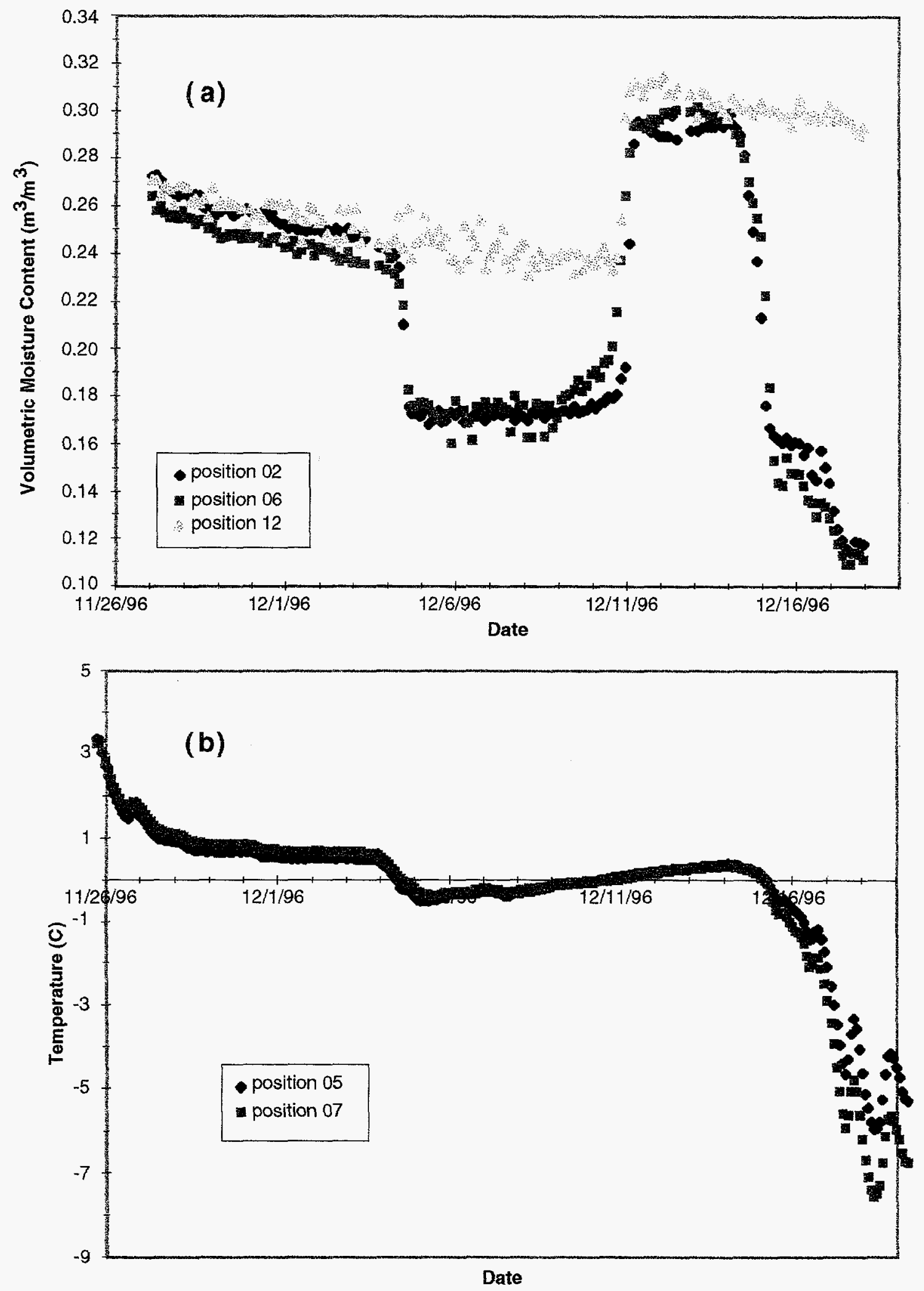

Figure 9. TDR measured soil moisture contents at the 20-cm depth in test plot B2 (a) and corresponding soil temperature data (b). 

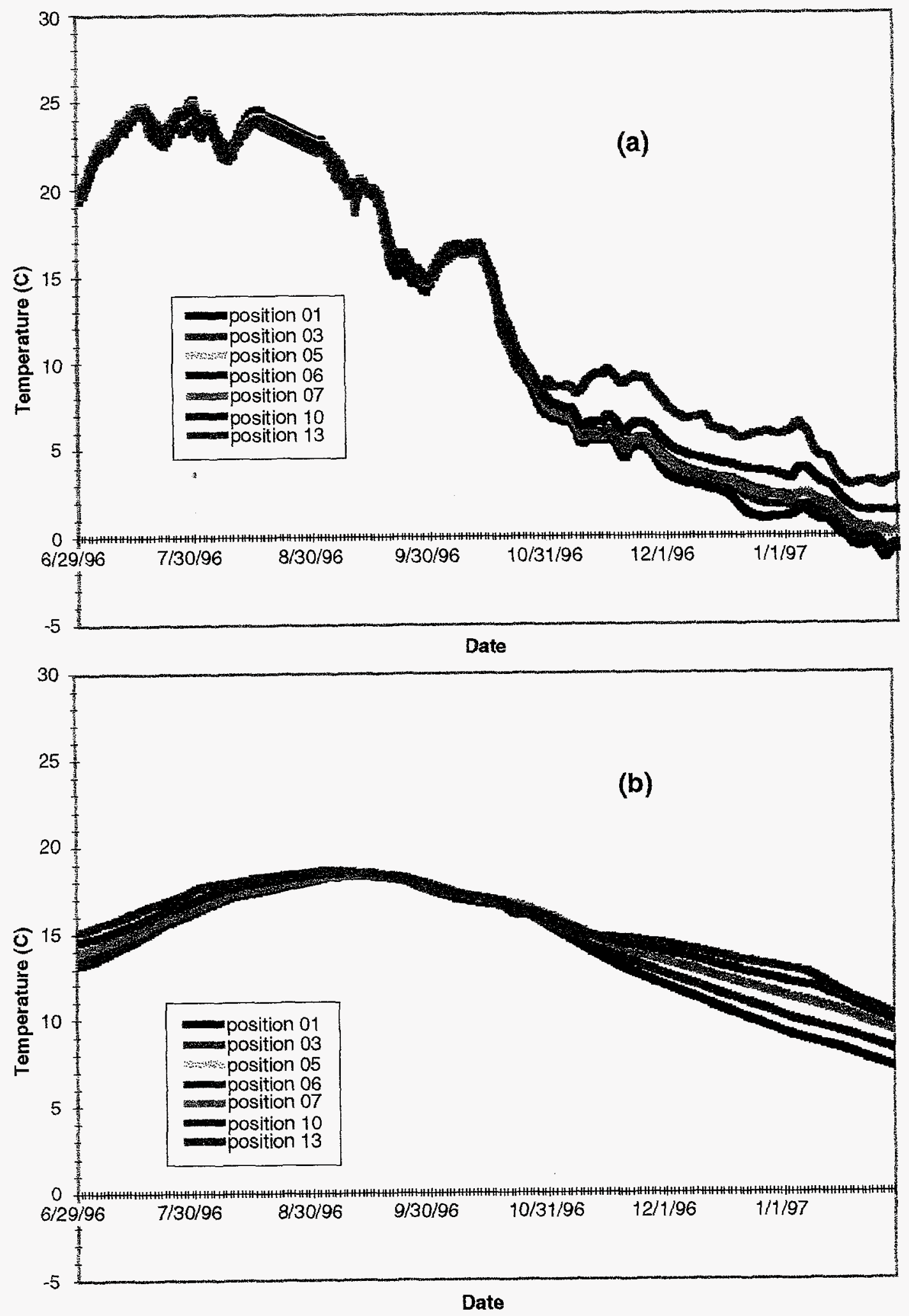

Figure 10. Soil temperature data from thermocouple transects at the (a) $60-\mathrm{cm}$ and (b) $270-\mathrm{cm}$ depths in test plot $\mathrm{B} 1$ (position 1 is farthest from the access trench wall and position 13 is closest to the wall). 

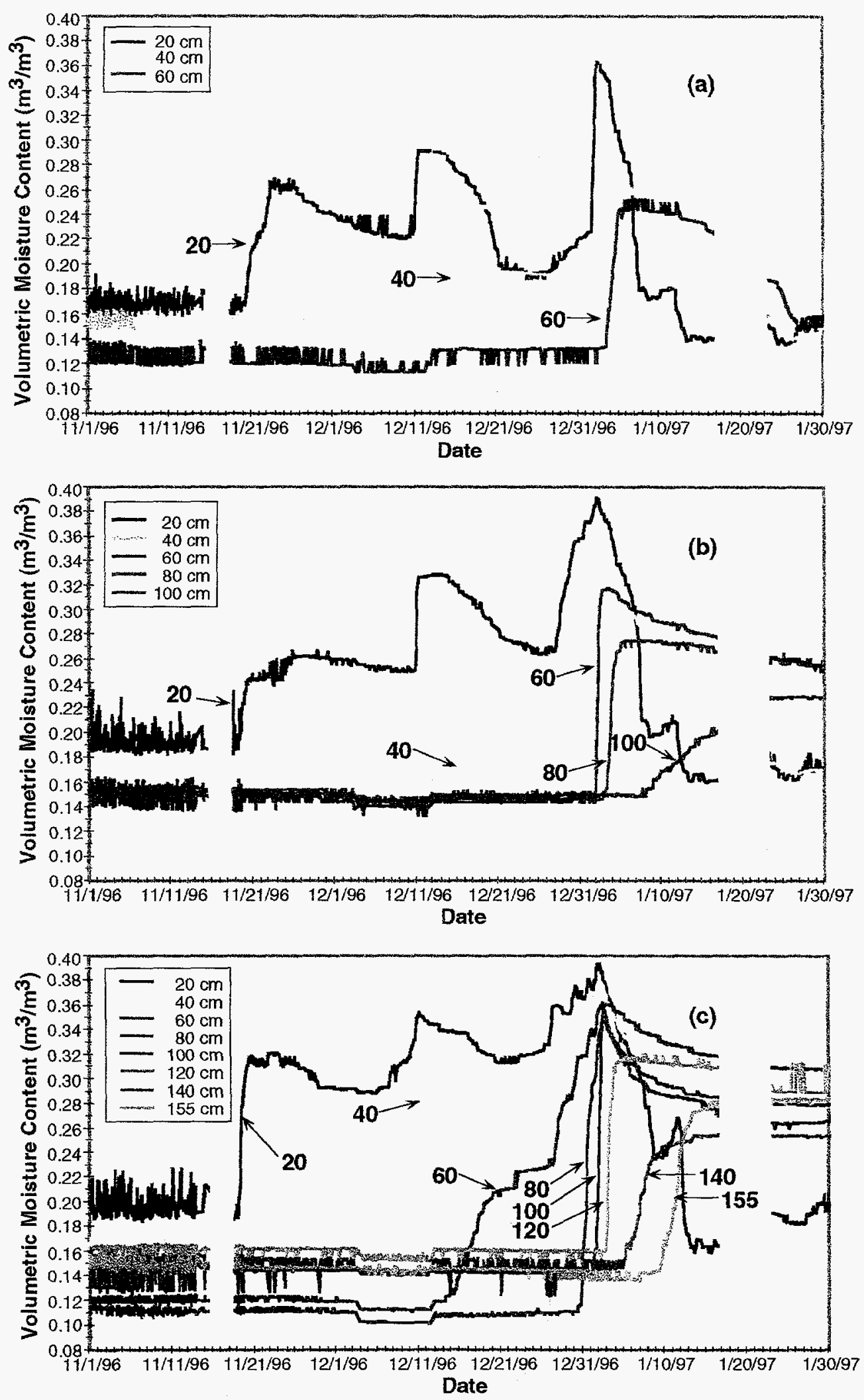

Figure 11. TDR soil moisture data from test plot B1 illustrating the progression of infiltration at positions 02 (a), 06 (b), and 12 (c). 


\subsubsection{Neutron Probe}

Figure 12 shows soil moisture profiles determined from neutron probe readings for test plots B1 (a and b) and SI (c and d). These profiles are typical of the profiles seen in the other test plots. The large leftward bulge in Figures $12 \mathrm{a}$ and $12 \mathrm{~b}$ denotes the bio/capillary barrier. Due to the large pore spaces in the gravel and cobble layers, the moisture content is very low compared to the soil layers above and below, thus making the bio/capillary barrier easy to distinguish in these graphs. Figure 13 shows the TDR soil moisture data corresponding to the neutron probe data in Figure 12.

The neutron probe data indicates that infiltration occurred between November 13 and 25 and between December 9 and January 24, confirming the TDR data in both Figures 13 and 11. Figures 12 and 13 show infiltration to depths of $15 \mathrm{~cm}$ and $20 \mathrm{~cm}$, respectively. These differences can be attributed to slightly different depths of measurement for the two different instruments, and to the larger radius of influence of the neutron probe. Neutron probe measurements in proximity to the surface and interfaces of different textures (as at the boundary of the bio/capillary barrier) are influenced by those regions, whereas TDR measurements are relatively unaffected. Figures $12 \mathrm{a}$ and $12 \mathrm{c}$ show that infiltration has reached the 137-cm depth on the east side of both the bio/capillary and thick soil test plots. Corresponding TDR measurements indicate infiltration down to $155 \mathrm{~cm}$ (Figures $13 \mathrm{a}$ and 13c). Figures $12 \mathrm{~b}$ and $12 \mathrm{~d}$ and $13 \mathrm{~b}$ and $13 \mathrm{~d}$ all show that infiltration has reached the $61-\mathrm{cm}$ depth on January 24.

Unlike the TDR probes, the neutron probe detects moisture in the soil regardless of its state (i.e., regardless of whether the moisture is liquid or frozen). The January 24 data confirm the observation from the TDR data that some of the moisture near the surface of the plots was frozen. Whereas the TDR moisture contents decreased as the surface is approached, the neutron probe moisture contents either stayed constant or increased. The decreasing moisture content near the surface in the TDR graphs reflects not drying but freezing of the soil. Both Figures 12 and 13 also show greater and deeper infiltration on the plot side closest to the access trench. Heat from the trench warmed the test plot causing a temperature gradient across the plot (i.e., the plot was warmer on the side closest to the access trench). Freezing of soil moisture near the surface limited infiltration and subsequent moisture flow through the soil on the west side of these plots compared to the east side. This, in combination with somewhat deeper (drifted) snow on the east side of the test plot, resulted in deeper infiltration on the east side.

\subsection{Matric Potential}

No single instrument has been developed that can provide reliable soil matric potentials over the entire range of potentials likely to be found in soil. At the EBTF, three types of instruments were installed. Each one works best in a separate range of potential, although the ranges overlap somewhat. Thermocouple psychrometers were calibrated in the range -5 to -25 bars, heat dissipation sensors were calibrated in the range -0.5 to -10 bars, and tensiometers function to a lower limit of about -0.8 bar.

\subsubsection{Thermocouple Psychrometers}

Figure 14 shows thermocouple psychrometer data from several depths in test plot B1. The thermocouple psychrometer data in test plot B1 are typical of all the test plots. Aside from fluctuations due to diurnal temperature changes in the uppermost thermocouple psychrometers, matric potentials were relatively steady and at or beyond the dry end of their calibration range throughout the summer. The first response to infiltration occurred at the $20-\mathrm{cm}$ depth around November 19. Matric potentials increased (i.e., the soil became wetter). This corresponds to moisture increases at this depth and location as recorded by the TDR 

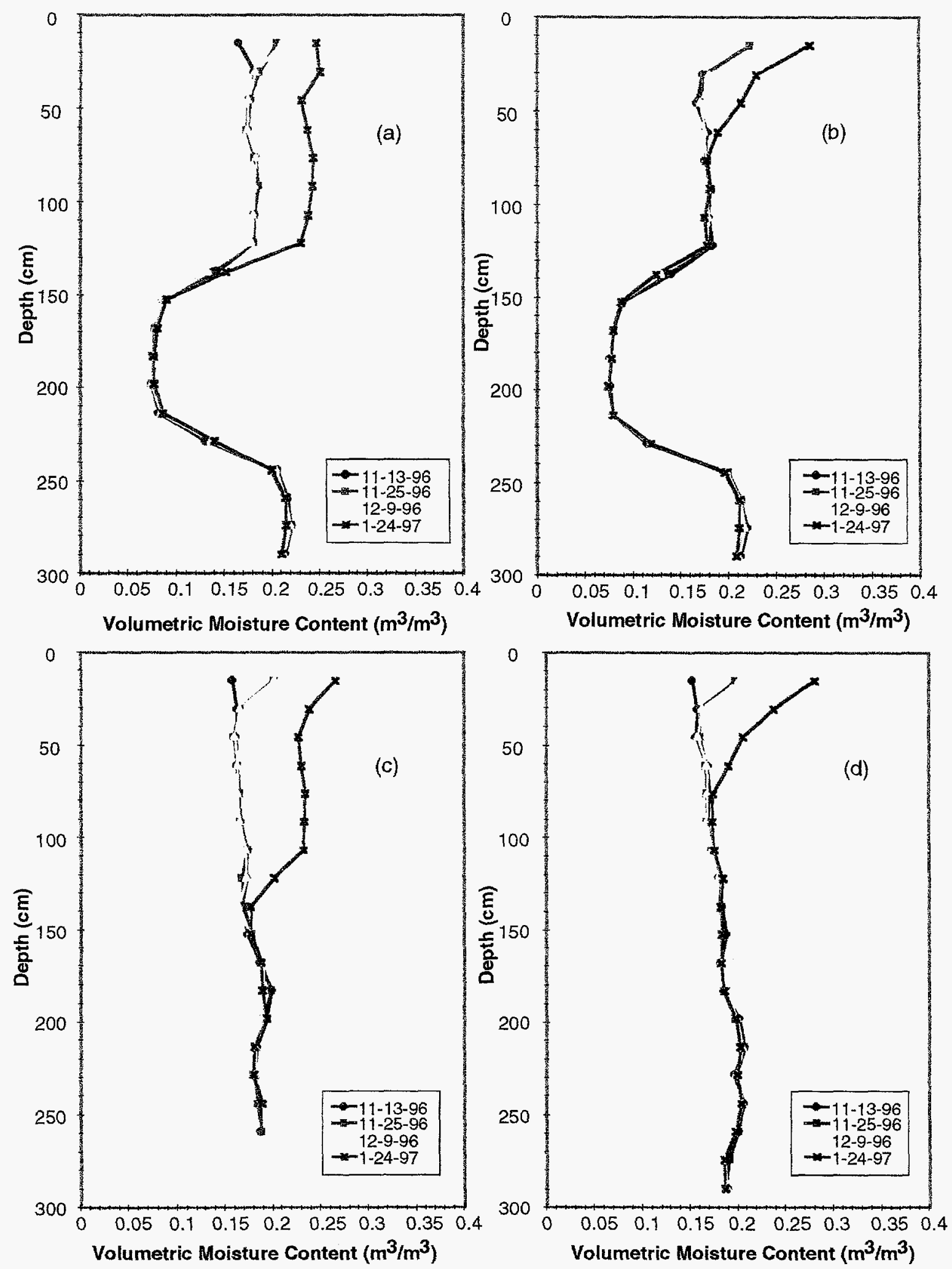

Figure 12. Neutron probe soil moisture profiles for test plots B1 ( $a$ and $b$ ) and S1 (c and d). 

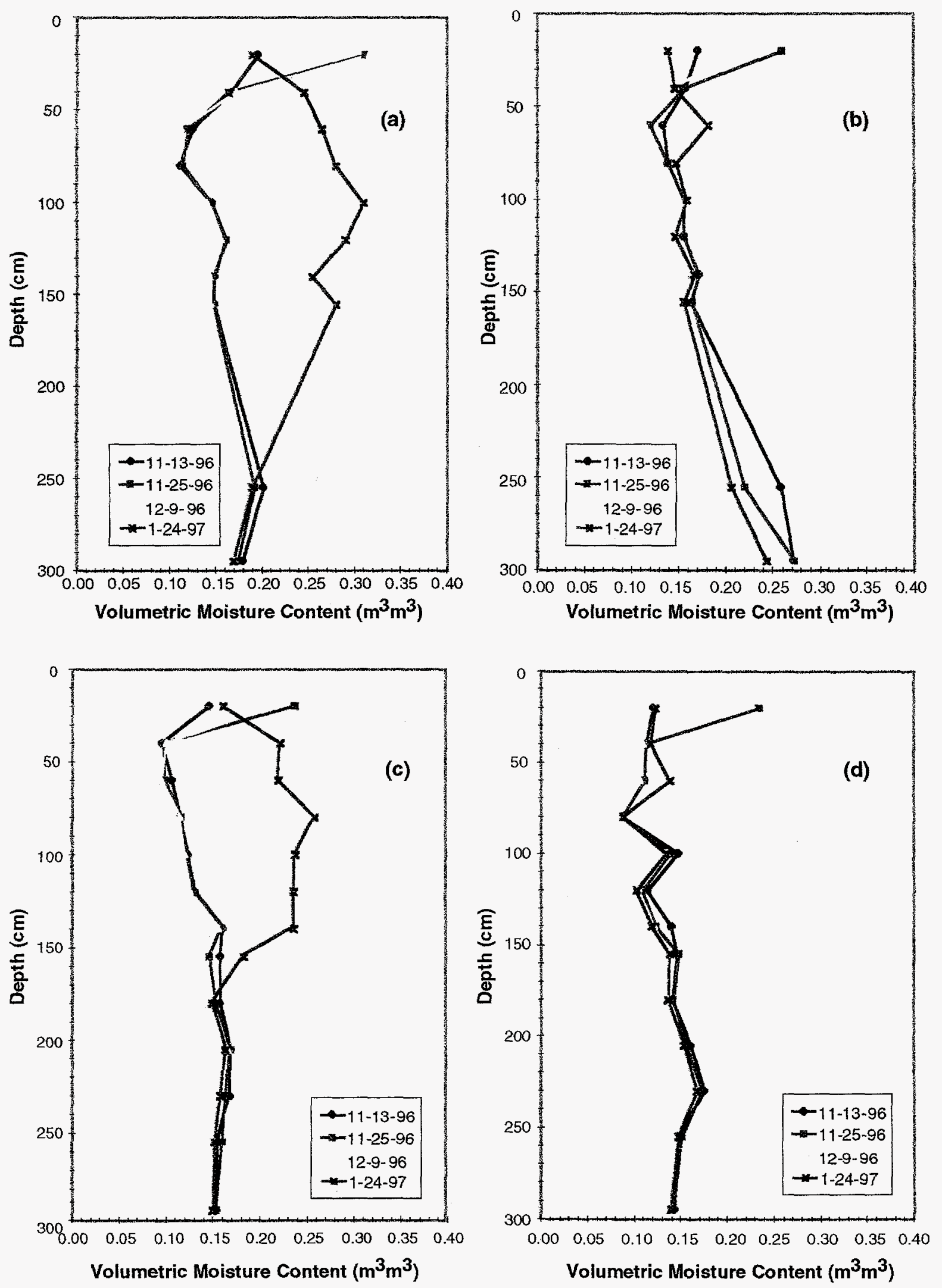

Figure 13. TDR soil moisture profiles for test plots $B 1$ ( $a$ and $b$ ) and $S 1$ (c and d). 

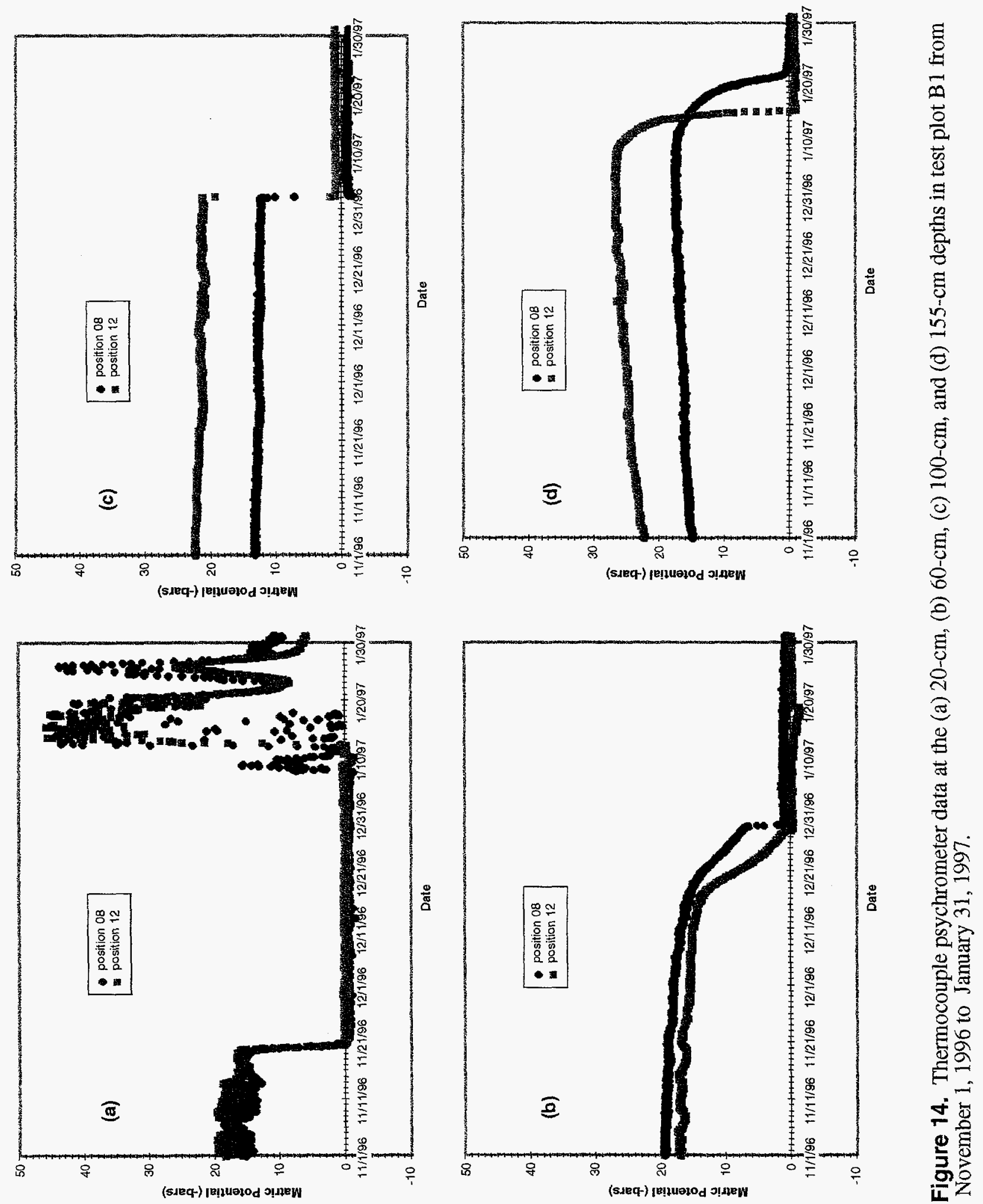
probes (see Figure 11c). Subsequent changes at the 60-, 100-, and 155-cm depths (Figures 14b, 14c, and 14d, respectively) also correspond to measured moisture increases (see Figure 11c). Infiltration at these four depths increased matric potentials beyond the upper limit of the calibrations. Matric potentials below $155 \mathrm{~cm}$ have not changed. Note that the two instruments at the $155-\mathrm{cm}$ depth responded at different rates. This may be due to a combination of soil and instrument variability at these two locations. Matric potentials at the $20-\mathrm{cm}$ depth decreased abruptly in early January and exhibited large changes throughout the rest of the month. These changes correspond to soil temperatures at the 20-cm depth dropping below zero (see Figure 15). Although frozen soil, in essence, is dry soil, with a concomitant low matric potential, these readings cannot be regarded as accurate because the thermocouple psychrometers have not been calibrated to determine the energy status of water in a solid (frozen) state.

\subsubsection{Heat Dissipation Sensors}

Figure 16 is typical of matric potential data in all test plots at the 20 - and $60-\mathrm{cm}$ depths as measured by heat dissipation sensors. Matric potentials were low (less than -10 bars - the lower limit of the calibration range) and fairly constant throughout the summer and fall. The sensors at the 20 -cm depths initially responded to increased matric potential around November 19 , with another noticeable response around December 9 (Figure 16a). These responses correspond to TDR-measured moisture content changes (see Figure 11a). At the 60-cm depth, matric potential began to increase initially around December 13, with a sharp response occurring around January 3, 1997 (Figure 16b). A second response occurred around January 18, 1997. The time difference between the second responses for the two sensors at the 60-cm depth illustrates spatial variability in soil properties at these two locations. The time difference is not as evident in the initial sharp response at this depth, nor is it evident in the responses at the 20-cm depth. With only one exception (test plot S3), matric potentials below $60 \mathrm{~cm}$ have remained relatively unchanged (and outside the calibrated range of the sensors) throughout the entire monitoring period. In test plot S3, matric potential has increased at the $100-\mathrm{cm}$ depth, but has remained constant at lower levels. These responses are consistent with both TDR- and neutron probe-measured moisture content changes on the far side (relative to the access trench wall) of the plot.

Figure 17 shows the matric potential profile in test plot B1 on January 31,1997 . This profile is typical of the test plots, wherein matric potentials were relatively high (and within the calibration range) at the 20- and 60-cm depth, low (and outside the calibration range) in the central portion of the plot, and intermediate (but still outside the calibration range) near the bottom of the plot.

\subsubsection{Tensiometers}

Tensiometers were filled and functioning at installation in the test plots. Although tensiometers generally require periodic servicing, tensiometers at the EBTF were not recharged throughout the summer and early fall because little rainfall occurred and none of the other data (soil moisture contents from TDR and neutron probe measurements and soil matric potentials from thermocouple psychrometer and heat dissipation sensor measurements) indicated that infiltration had occurred. It was thought that soil matric potentials were beyond the tensiometric range (too dry). By October, most tensiometers were indicating matric potentials of zero (i.e., they did not appear to be functioning). However, 23 of the 32 tensiometers at the 255- and 295-cm depths continued to give non-zero reading (even though thermocouple psychrometers and heat dissipation sensors were indicating that matric potentials were on the order of -10 bars or lower. It is questionable whether these tensiometer readings are accurate. 


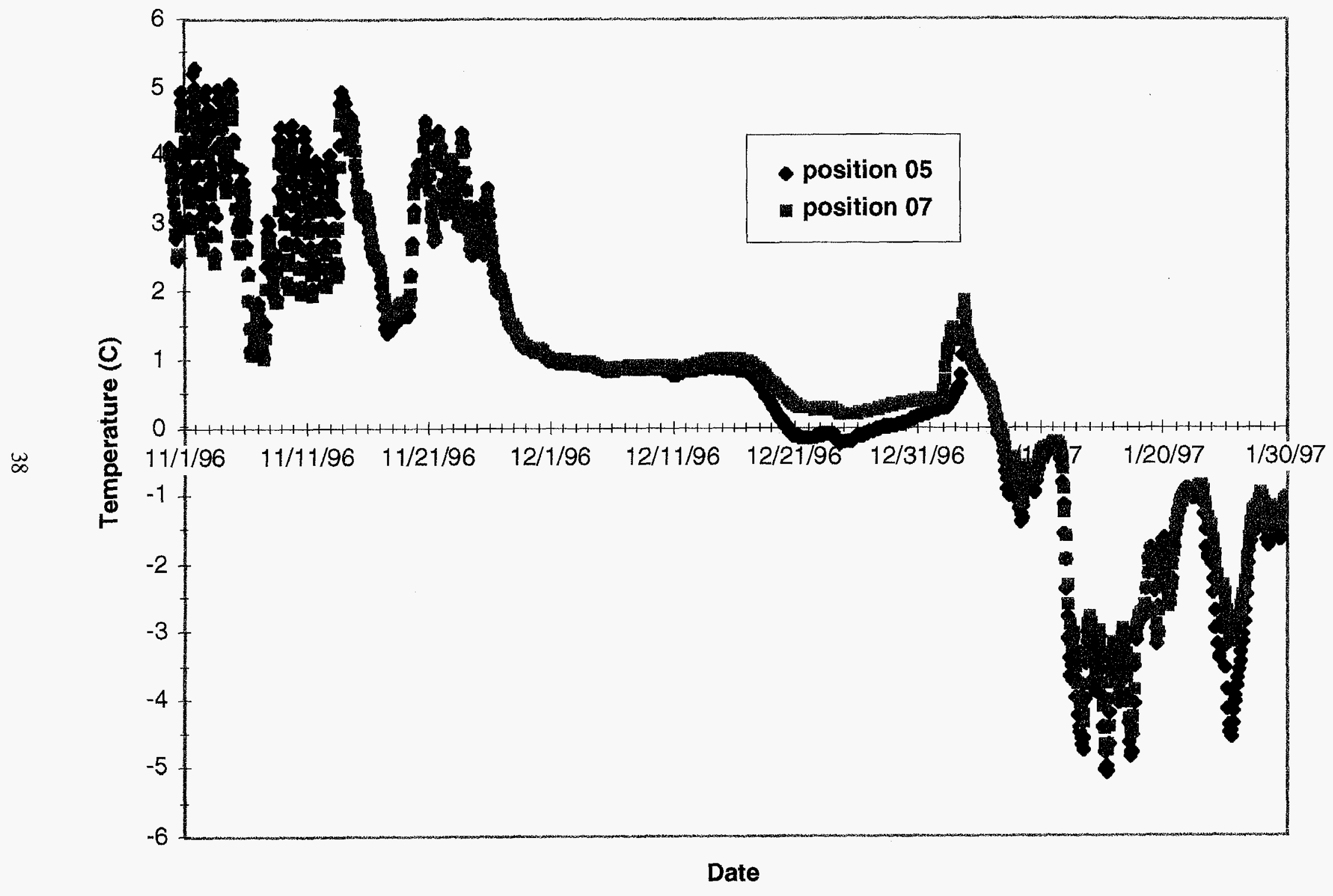

Figure 15. Soil temperatures at the 20-cm depth in test plot B1. 

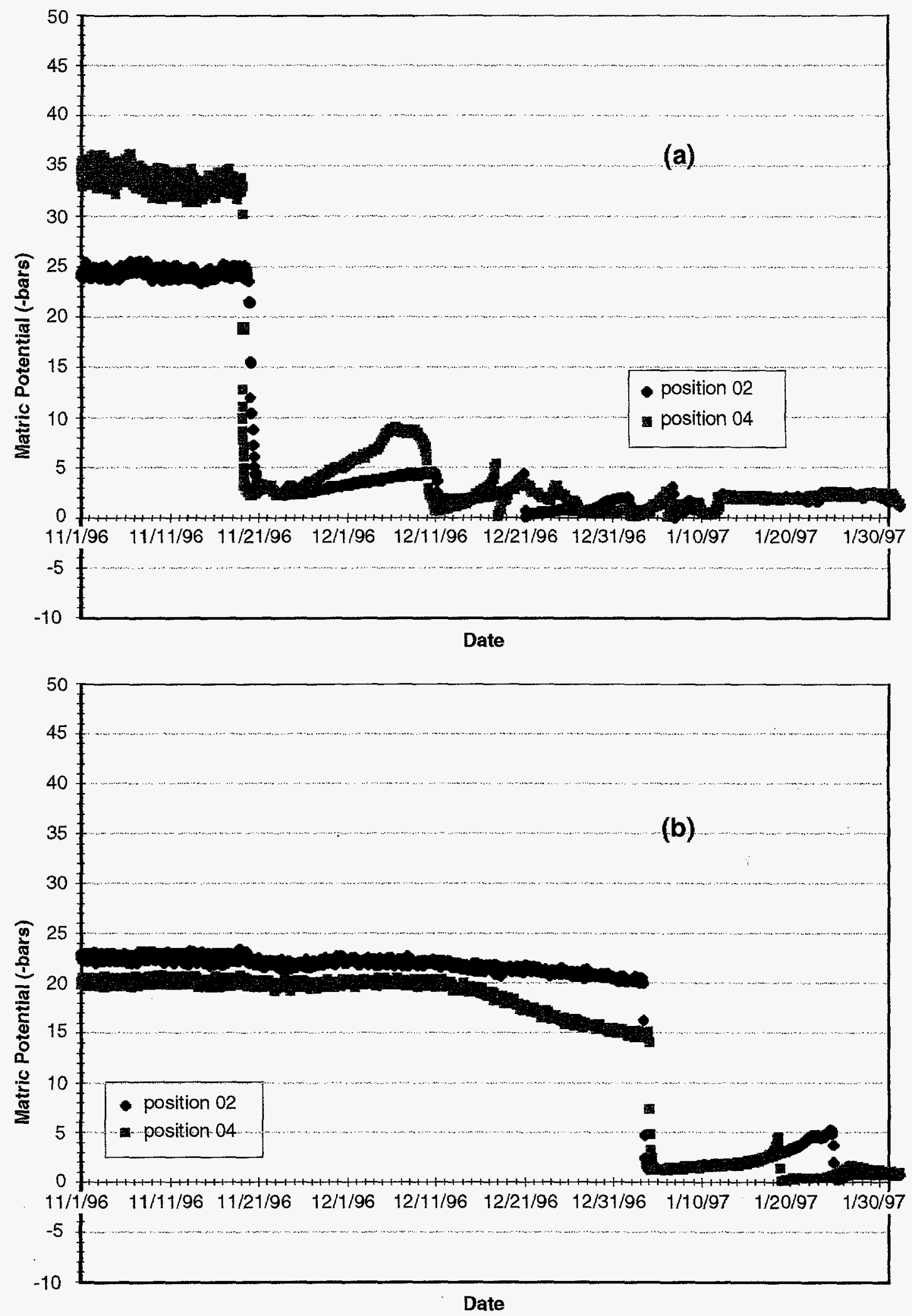

Figure 16. Heat dissipation sensor data at the (a) $20-\mathrm{cm}$ and (b) $60-\mathrm{cm}$ depths in test plot B1 from November 1, 1996 to January 31, 1997. 


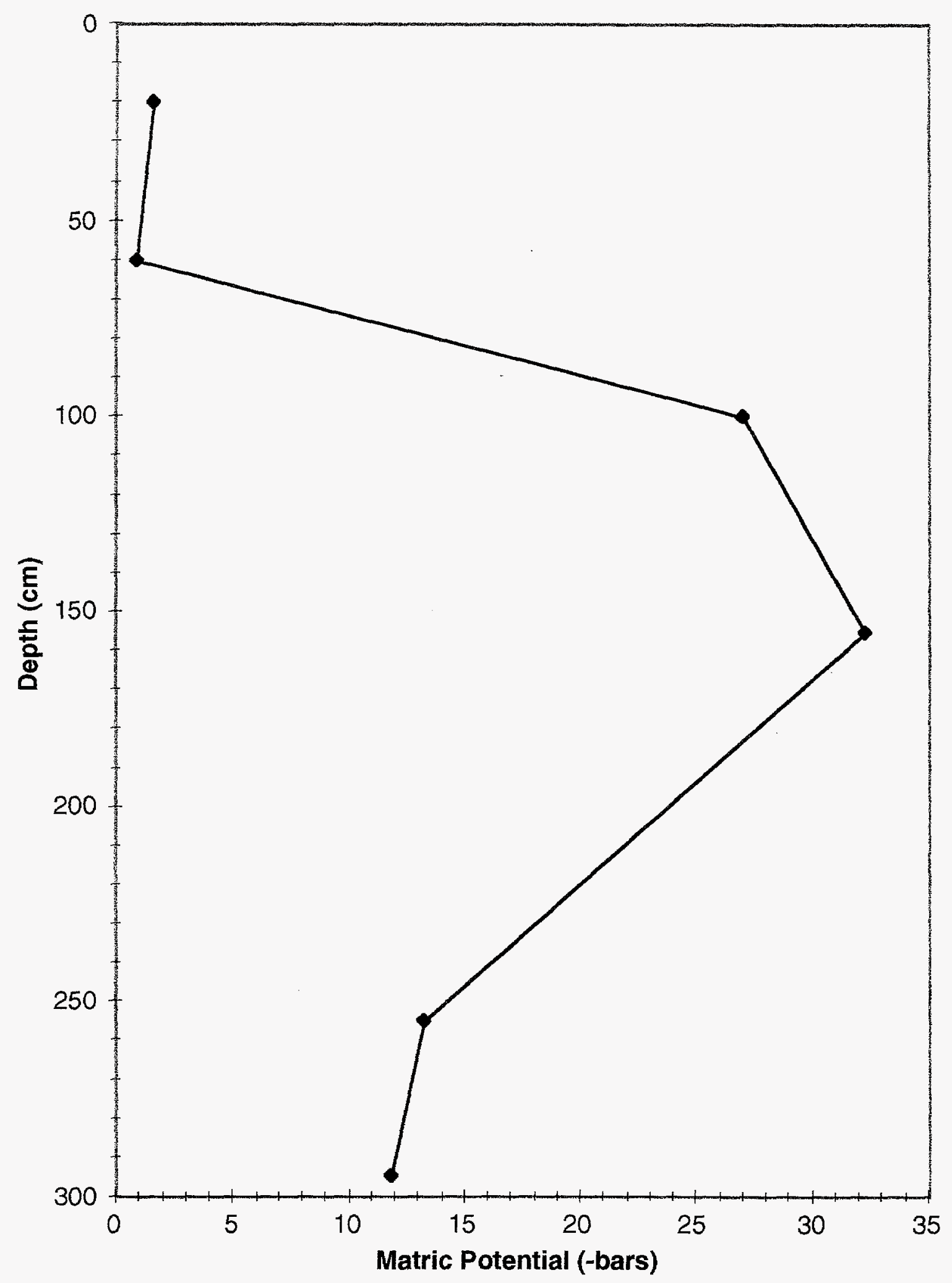

Figure 17. Soil matric potential profile from heat dissipation sensor data in test plot B1 on January $31,1997$. 
Tensiometers were recharged at the beginning of October and again at the beginning of January. Again, with the exception of 23 of the 32 tensiometers at the 255- and 295-cm depths, almost all of the tensiometers installed in position 10 went to zero matric potential sometime between October and December. Most of the tensiometers in position 03 continued to give readings. Again, non-zero tensiometer readings were at odds with other instrument data which indicated fairly dry soil conditions during October and November. Tensiometers in position 10 are $110 \mathrm{~cm}$ long (compared to $248 \mathrm{~cm}$ for tensiometers in position 03). The shorter length may be a reason why tensiometers in position 10 stop working sooner than those in position 03. These tensiometers hold less water and, as a result, lose this water quicker under dry conditions. Other instruments (TDR, neutron probe, thermocouple psychrometers, and heat dissipation sensors) showed infiltration starting in the later half of November and continuing through December and January. These instruments show infiltration progressing deeper into the soil profile with time. Tensiometers that appear to respond to soil matric potential changes during this time do not show this downward progression in an orderly fashion (i.e., tensiometers at deeper depths respond before those at shallower depths). Therefore, tensiometers with readings that go to zero during this period are most likely not functioning. It is also likely that tensiometers in position $\mathbf{0 3}$ are not functioning, but, because they hold more water, they continue to provide a reading. Soil moisture characteristics that link matric potential and soil moisture, once they are determined for samples collected from the test plots, may provide data that allow more definitive interpretation of the tensiometer data.

\section{REFERENCES}

Bishop, C. W., 1996, Soil Moisture Monitoring Results at the Radioactive Waste Management Complex of the Idaho National Engineering Laboratory, FY-96, FY-95, and FY-94, INEL-96/297, Lockheed Martin Idaho Technologies Company, Idaho Falls, Idaho.

D. B. Stephens and Associates, Inc., 1996, Calibration of Heat Dissipation and Thermocouple Psychrometer Probes, Albuquerque, New Mexico.

Kaser, T. G., and M. K. Adler Flitton, 1997, Data Acquisition System for RWMC SDA Engineered Barriers Test, INEL-96/311, Lockheed Martin Idaho Technologies Company, Idaho Falls, Idaho.

Porro, I., K. N. Keck, D. L. McElroy, and C. W. Bishop, 1996, RWMC SDA Engineered-Barrier Test Plan, INEL-96/0003, Lockheed Martin Idaho Technologies Company, Idaho Falls, Idaho.

Topp, G. C., J. L. Davis, and A. P. Annan, 1980, "Electromagnetic Determination of Soil Water Content: Measurements in Coaxial Transmission Lines," Water Resources Research, 16(3), pp. 574-582. 